Article

\title{
Circular Building Process: Reuse of Insulators from Construction and Demolition Waste to Produce Lime Mortars
}

\author{
Daniel Ferrández ${ }^{1}$, Engerst Yedra ${ }^{1}$, Carlos Morón ${ }^{1, * \mathbb{D}}$, Alicia Zaragoza ${ }^{1}$ and Marta Kosior-Kazberuk ${ }^{2} \mathbb{D}$ \\ 1 Departamento de Tecnología de la Edificación, Escuela Técnica Superior de Edificación, \\ Universidad Politécnica de Madrid, 28040 Madrid, Spain; daniel.fvega@upm.es (D.F.); \\ e.yedra@alumnos.upm.es (E.Y.); alicia.zaragoza@alumnos.upm.es (A.Z.) \\ 2 Department of Building Structures, Bialystok University of Technology, 15-351 Bialystok, Poland; \\ m.kosior@pb.edu.pl \\ * Correspondence: carlos.moron@upm.es; Tel.: +34-91-336-7583; Fax: +34-91-336-7637
}

check for updates

Citation: Ferrández, D.; Yedra, E.;

Morón, C.; Zaragoza, A.; Kosior-Kazberuk, M. Circular Building Process: Reuse of Insulators from Construction and Demolition Waste to Produce Lime Mortars. Buildings 2022, 12, 220. https:// doi.org/10.3390/buildings12020220

Academic Editors: Paulo Santos and Mark Bomberg

Received: 18 January 2022

Accepted: 10 February 2022

Published: 16 February 2022

Publisher's Note: MDPI stays neutral with regard to jurisdictional claims in published maps and institutional affiliations.

Copyright: (C) 2022 by the authors. Licensee MDPI, Basel, Switzerland. This article is an open access article distributed under the terms and conditions of the Creative Commons Attribution (CC BY) license (https:// creativecommons.org/licenses/by/ $4.0 /)$.

\begin{abstract}
This research aims to revalue the possibilities presented by lime mortars for use in renovation and as cladding material on facades. The study focuses on analyzing the technical feasibility of lime mortars with the incorporation of residues from three types of thermal insulation materials: expanded polystyrene with graphite especially suitable for use on facades; expanded polystyrene for use indoors; and insulating mineral wool. The incorporation of these construction and demolition residues makes it possible to improve several technical performance aspects of lime mortars, and to incorporate circular economy criteria in the manufacturing process of these materials. The results showed that the incorporation of mineral wool improves the mechanical resistance to the bending of mortars, increases their durability against freeze-thaw cycles and salt crystallization, and reduces the final shrinkage of mortars. For their part, mortars with the addition of polystyrene-insulating residues reduce mechanical resistance, but also reduce thermal conductivity, and are lighter, which is why they are shown as a possible alternative for use in precast.
\end{abstract}

Keywords: lime mortars; thermal insulation materials; rehabilitation; construction and demolition waste; sustainable building

\section{Introduction}

Currently, in the European Union, approximately $40 \%$ of total energy consumption is caused by residential buildings, tertiary buildings, shops, offices, and other auxiliary buildings [1]. In Spain, this percentage is reduced to $27.7 \%$ due to the better climatic conditions offered by being located in southern Europe [2]. However, this is still a high, and not inconsiderable percentage, meaning that every day more researchers seek to take action to evolve towards a more sustainable building sector [3]. If we continue to limit the problem to Spain, the gradual aging of the building stock increasingly forces autonomous governments to implement energy rehabilitation policies [4]. In Spain alone, more than half of the 25.7 million existing homes and buildings-according to the Ministry of Transport, Mobility and Urban Agenda (MITMA) [5] — were built before the first energy regulation was approved [6], NBE-CT 79 [7]. In this sense, any action aimed at reducing energy consumption, the emission of greenhouse gases, the environmental impact of buildings, and the excessive consumption of natural resources in construction [8-10], is in line with the Goals for Sustainable Development (SDG) set by the United Nations [11]. More specifically, this work is directly linked to SDGs 11 and 12: "Sustainable Cities and Communities" and "Responsible Production and Consumption", although it is a cross-sectional investigation shared with other goals set for 2030.

Together with the problem of high energy consumption in buildings, the European continent faces the challenge of carrying out adequate management of the construction and demolition waste (CDW) that is generated annually [12], and that represents between 
$25-30 \%$ of the solid waste produced (approximately 800 million tons per year) [13]. For this purpose, the European Commission has developed a series of guidelines to improve the identification of CDW and enhance their separation and collection at source (European Commission, 2018 [14]), so that it is possible to recycle, reuse and recover at least $70 \%$ by weight of the non-hazardous CDW generated $[15,16]$. For this reason, within the framework of the European Green Deal [17], the CDW is placed as a priority axis to achieve the elaboration of a circular economy action plan in the European Union [18], due to the great potential that these residues present for their reincorporation into the production process and the generation of new raw materials [19].

Traditionally, hydraulic lime mortars made with river sand have been used in façade rehabilitation works using continuous granulometry with aggregate fractions between $0-4 \mathrm{~mm}[20,21]$. The importance of maintaining a careful granulometry and a clean aggregate becomes even greater if it is intended to produce precast lime [22], since an adequate proportion of fines provides a compact structure and better mechanical performance to the constructive element [23]. It should be noted that lime mortars fell into disuse from the 19th century with the industrial revolution and the cement boom [24], although there are certain properties such as their high plasticity and good workability that make them essential for some forms of restoration and building rehabilitation works $[25,26]$. Hydraulic lime mortars, in turn, have good permeability and great water retention; these properties are especially relevant when you want to avoid humidity by condensation [27]. Furthermore, as some researchers have verified, hydraulic lime mortars have higher mechanical strength at early ages and are set faster than area lime mortars [28]. From an environmental point of view, some researchers have observed how lime can absorb $\mathrm{CO}_{2}$ from the air gradually, increasing its rigidity and improving the building's carbon footprint during its useful life $[29,30]$.

In recent decades, studies have been carried out aimed at incorporating recycled materials from CDW in the manufacture of mortars, to reduce the volume that this type of waste occupies in the landfill and give them a new useful life [31]. In Spain, more than 21.5 million tons/year of these wastes are produced [32]. The most common way to incorporate these CDWs in the manufacture of mortars is by grinding and cleaning to use them as recycled aggregates in total or partial replacement of natural aggregate [33,34]. However, some wastes, such as those from thermal insulation materials for façades, can be used to lighten the weight of the binder materials and improve their thermal conductivity [35]. Following this line of research, Milling et al. investigated the possibility of replacing part of the cement content of masonry mortars with a mixture of expanded polystyrene (EPS) waste dissolved in acetone, where the results show that it is possible to obtain technically feasible mortars that significantly reduce the carbon footprint of these materials [36]. This type of EPS waste has also been studied by other researchers to develop low-density precast blocks that meet the minimum requirements for durability and mechanical resistance for use in buildings [37]. In any case, it is a waste that can be incorporated into building conglomerate materials to improve its thermal conductivity and promote the application of this type of mortar as an insulation system [38]. On the other hand, other authors have opted for the use of crushed mineral wool in cement mortars, mainly due to the good cohesion between the wool fibers and the mortar matrix, obtaining good flexural tensile results and improved thermal insulation properties [39]. In addition, this type of insulating mineral wool used as reinforcing fibers serves to significantly improve other properties of mortars, such as resistance to cracking, decreases in shrinkage, or improvements to the modulus of elasticity of mortars [40].

The main objective of this work was to study the technical feasibility of lime mortars with the incorporation of CDW from out-of-use thermal insulation materials. More specifically, an experimental campaign was developed with mechanical, physical, and durability tests, to find out the most relevant properties of lime mortars with the incorporation of three types of recycled insulators (expanded polystyrene recommended for use on façades, expanded polystyrene for interior use, and mineral wool) in two different proportions each. 


\section{Materials and Methods}

This section describes the materials used for the preparation of lime mortars, as well as the dosages used, and the experimental campaign carried out.

\subsection{Materials Employed}

For this work, the following raw materials were used in the preparation of mortars: hydraulic lime, natural aggregate (NA), expanded polystyrene insulation with graphite for use in facades (EPS-F), expanded polystyrene insulation for indoor use (EPS-I), mineral wool insulation (MW), and water.

\subsubsection{Hydraulic Lime}

The conglomerate material chosen in this investigation was hydraulic lime. This material has the property of being able to set and harden with water, thanks to its composition generally made up of $\mathrm{Ca}(\mathrm{OH})_{2}$, calcium silicates, and calcium aluminates [41]. More specifically, a hydraulic lime of the NHL-5 type was used, following the classification included in the UNE-EN 459-1: 2002 standard [42].

The technical characteristics of this raw material according to the manufacturer Chaux de Saint-Astier are shown in Table 1. Furthermore, according to the procedure included in the UNE 80103: 2013 [43] standard, it was determined that the real density of the lime used in this study would be $2750 \mathrm{~kg} / \mathrm{m}^{3}$.

Table 1. Technical characteristics of NHL 5 hydraulic lime [44].

\begin{tabular}{ccccc}
\hline $\begin{array}{c}\text { Start of Setting } \\
(\mathbf{m i n})\end{array}$ & $\begin{array}{c}\text { Fineness Blaine } \\
\left(\mathbf{c m}^{\mathbf{2}} \mathbf{/ g}\right)\end{array}$ & $\begin{array}{c}\text { Expansion } \\
(\mathbf{m m})\end{array}$ & $\begin{array}{c}\text { Free Water } \\
(\mathbf{\%})\end{array}$ & $\begin{array}{c}\text { Compression } \\
\text { Resistance (MPa) }\end{array}$ \\
\hline$\geq 60$ & 7882 & 0.80 & 0.55 & $\geq 5.00$ \\
\hline
\end{tabular}

\subsubsection{Natural Aggregate}

The aggregate used to make the mortars was river natural sand. Figure 1 shows the granulometry of the sands used in this investigation. The granulometric curve was obtained using the dried aggregate and a series of standardized sieves according to UNE-EN 933-2 with a mesh opening between 4.000 and $0.063 \mathrm{~mm} \mathrm{[45].} \mathrm{It} \mathrm{was} \mathrm{sought} \mathrm{to} \mathrm{obtain} \mathrm{a} \mathrm{continuous}$ granulometry in order to improve the compactness of hardened lime mortars [46].

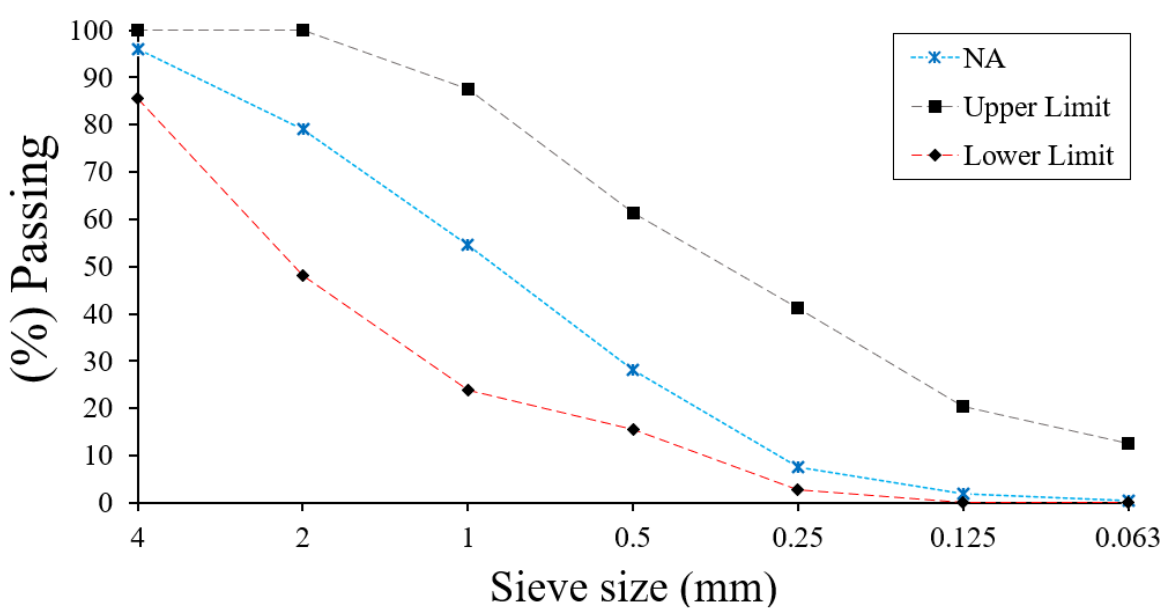

Figure 1. Recycled aggregate size distribution curve compared to the limits of NBE FL-90 [47] adapted to sieve size established by UNE-EN-933-2 [45].

On the other hand, Table 2 shows the results of the physical characterization of the sands used, following the recommendations of the UNE-EN 13139: 2002 standard [48]. 
Table 2. Physical characterization of the natural river sand.

\begin{tabular}{|c|c|c|c|c|c|c|}
\hline Test & $\begin{array}{c}\text { Fine } \\
\text { Content } \\
(\%)\end{array}$ & $\begin{array}{c}\text { Fineness } \\
\text { Modulus } \\
(\%)\end{array}$ & $\begin{array}{c}\text { Friability } \\
(\%)\end{array}$ & $\begin{array}{c}\text { Bulk } \\
\text { Density } \\
\left(\mathrm{kg} / \mathrm{m}^{3}\right)\end{array}$ & $\begin{array}{c}\text { Dry } \\
\text { Density } \\
\left(\mathrm{kg} / \mathrm{m}^{3}\right)\end{array}$ & $\begin{array}{c}\text { Water } \\
\text { Absorption } \\
(\%)\end{array}$ \\
\hline \multirow{2}{*}{ Standard } & UNE EN & UNE-EN & UNE-EN & UNE-EN & UNE-EN & UNE-EN \\
\hline & 933-1 [49] & 13139 [48] & 146404 [50] & $1097-3$ [51] & $1097-6$ [52] & $1097-6$ [52] \\
\hline NA & 1.92 & 4.21 & 20.76 & 1569 & 2517 & 0.87 \\
\hline
\end{tabular}

\subsubsection{Waste from Thermal Insulation Materials}

In this work, three different types of insulation materials from construction and demolition waste were used: expanded polystyrene insulation with graphite for use on facades (EPS-F); expanded polystyrene insulation for indoor use (EPS-I); and mineral wool insulation (MW), as shown in Figure 2.

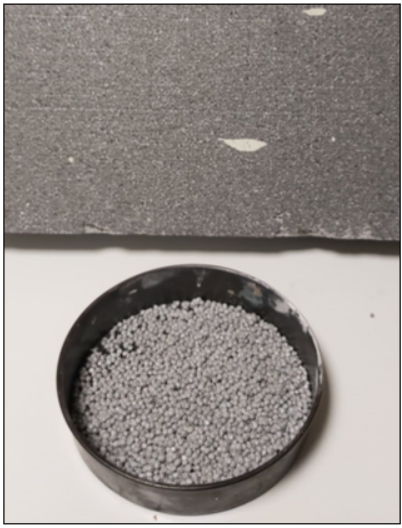

(a)

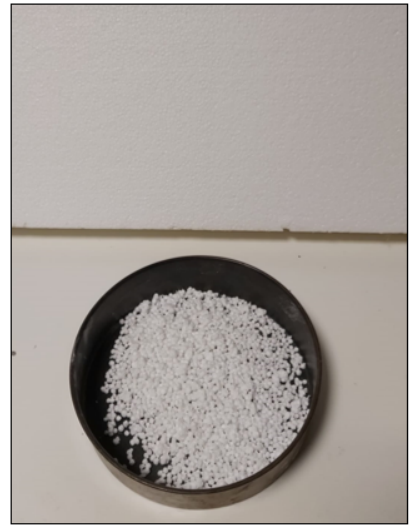

(b)

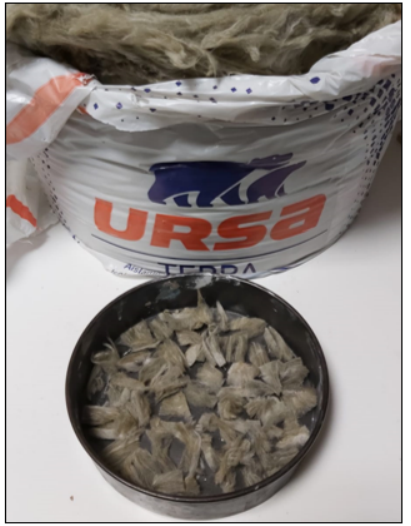

(c)

Figure 2. Waste insulation used. (a) Expanded polystyrene with graphite for use in facades; (b) expanded polystyrene for indoor use; (c) mineral wool.

These wastes were obtained from a recycling plant located in El Molar (Madrid, Spain) and had to be collected and separated manually. In the case of polystyrene insulators, they were prepared manually according to the procedure used in other investigations to break them down into small spheres that could be added during the manufacture of mortars [53,54]. For its part, the mineral wool insulation was manually shredded and separated into fibers of $12 \mathrm{~mm}$ length, following the recommendations found in the literature $[55,56]$. Its most relevant characteristics are collected in Table 3.

Table 3. Physical characteristics of the insulation waste used (URSA Ibérica Aislantes, S.A., Madrid, Spain).

\begin{tabular}{ccccc}
\hline Type & Density $\left(\mathbf{k g} / \mathbf{m}^{\mathbf{3}}\right)$ & $\begin{array}{c}\text { Thermal Conductivity } \\
\mathbf{( W / m K )}\end{array}$ & $\begin{array}{c}\text { Water Diffusion Resistance } \\
\text { Factor (Dimensionless) }\end{array}$ & $\begin{array}{c}\text { Geometric } \\
\text { Characteristics }\end{array}$ \\
\hline EPS-F & 30 & 0.032 & $20-100$ & $\varnothing \mathrm{med}=5 \mathrm{~mm}$ \\
\hline EPS-I & 15 & 0.038 & $20-100$ & $\varnothing \mathrm{med}=3 \mathrm{~mm}$ \\
\hline MW & 40 & 0.040 & 1 & Lmed $=12 \mathrm{~mm}$ \\
\hline
\end{tabular}

\subsubsection{Water}

Safe drinking water from the Canal de Isabel II of the Community of Madrid (Spain) was used to mix the different mortar samples. This water has been used previously in research work [57], due to its good characteristics for making mortars. Its main properties 
include its soft hardness $(25 \mathrm{mg} \mathrm{CaCO} / \mathrm{L})$ and neutral $\mathrm{pH}$ between 7 and 8 recommended to avoid setting alterations [58].

\subsection{Dosages Used}

In this work, we intended to study the effect that the incorporation of thermal insulation materials in different proportions has on lime mortars, analyzing their physicalmechanical properties for their use as construction material. For this, two different proportions of insulating waste of each type and a single lime/aggregate ratio were incorporated. The mixing process was carried out following the recommendations of the UNE-EN 1961 [59] standard, with the help of an IBERTEST planetary mixer model IB32-040V01, and always following the same techniques and methods. The following nomenclature was defined for the different batches:

$$
\text { LM-Type-Quantity }
$$

where LM refers to the type of material used, lime mortars with a cement/aggregate ratio 1:3; Type refers to the insulation material incorporated in the manufacturing, which can be expanded polystyrene recommended for use on facades (EPS-F), expanded polystyrene for interior use (EPS-I), mineral wool (MW) or reference without insulation (REF); and finally, Quantity indicates the incorporated mass in grams of each type of waste, which can be 2.5 or $4.5 \mathrm{~g}$.

Table 4 shows the different proportions of each material used to make the lime mortars used in this research.

Table 4. Mixtures proportions by weight and workability of the test mortars.

\begin{tabular}{cccccc}
\hline Mortar Type & Lime (g) & Sand $(\mathbf{g})$ & Water (g) & $\begin{array}{c}\text { Insulating Waste } \\
\text { (g) }\end{array}$ & $\begin{array}{c}\text { Flow Table Workability } \\
\text { (mm) UNE-EN } \\
\text { 1015-3:2000/A2:2007 [60] }\end{array}$ \\
\hline LM-REF & & & 333 & - & 152 \\
LM-EPS-I-2.5 & 450 & 1350 & 369 & 2.5 & 156 \\
LM-EPS-I-4.5 & 450 & 1350 & 396 & 4.5 & 147 \\
LM-EPS-F-2.5 & 450 & 1350 & 378 & 2.5 & 153 \\
LM-EPS-F-4.5 & 450 & 1350 & 405 & 4.5 & 151 \\
LM-MW-2.5 & 450 & 1350 & 360 & 4.5 & 152 \\
LM-MW-4.5 & 450 & 1350 & 387 & & 146 \\
\hline
\end{tabular}

As shown in Table 4, the water content was set experimentally following the indications of the UNE-EN 1015-3:2000/A2:2007 [60] standard, until achieving a workable consistency corresponding to a diameter of the $150 \pm 10 \mathrm{~mm}$ mortar cake in the flow table workability. It can also be seen that mortars with higher incorporation of insulating residue ( $4.5 \mathrm{~g}$ ) required a higher content of mixing water, which had a negative influence on the mechanical resistance of these materials [61]. Finally, it should be noted that the different samples produced were cured in a humid chamber for 28 days, at a temperature of $22 \pm 2{ }^{\circ} \mathrm{C}$ and relative humidity of $95 \%$ [62].

\subsection{Experimental Study}

The experimental program included in this research work includes a mechanical, physical, and durability characterization of lime mortars with the incorporation of three types of thermal insulation materials.

Regarding the mechanical characterization, flexural and compression failure tests were carried out on standardized $4 \times 4 \times 16 \mathrm{~cm}$ RILEM specimens, following the recommendations of the UNE-EN 1015-11:2000/A1:2007 standard [63]. The results were obtained with the help of a model AUTETEST 200-10SW press, and the fractography derived from the breakage of the specimens in the bending test was analyzed. 
For its part, the physical characterization included the performance of five tests. Shore D surface hardness was used to determine the wear resistance of mortars and the possibility of being scratched on their surface: for this we used a Shore D durometer and $4 \times 4 \times 16 \mathrm{~cm}$ test tubes. We also tested the adhesion of lime mortars made on ceramic surfaces, for which the recommendations of the UNE-EN 1015-2:1999/ A1:2007 [64] standard were followed, applying a mortar mass of $10 \pm 1 \mathrm{~mm}$ thick on a previously moistened ceramic scraper and using direct traction equipment with cylindrical specimens with a diameter of $50 \mathrm{~mm}$. Next, we assessed water absorption by capillarity in mortars, following the recommendations of the UNE-EN 1015-18 [65] standard, and the apparent density of mortars in the hardened state, using a precision balance with three significant figures and $4 \times 4 \times 16 \mathrm{~cm}$ test tubes. Finally, we assessed the coefficient of thermal conductivity of mortars, determined by the heat flow meter method and using Fourier's Law.

Finally, the durability tests that were carried out were: resistance to freeze-thaw cycles; salt crystallization; and shrinkage measurement. In the first two, freezing and crystallization of salts, the standards UNE-EN 12371 [66] and UNE-EN 12370 [67] were adapted for natural stone, respectively, using $4 \times 4 \times 16 \mathrm{~cm}$ series of test tubes and taking for each sample subjected to cycles, another equivalent without accelerated aging. The freeze-thaw cycles were completed 25 times $\left(6 \mathrm{~h}\right.$ freezing at $-12{ }^{\circ} \mathrm{C}$ and $18 \mathrm{~h}$ saturation in water at $\left.20^{\circ} \mathrm{C}\right)$ and the salt crystallization cycles were completed 15 times $(2 \mathrm{~h}$ in a solution of sodium sulfate decahydrate saturated with water), with $14 \%$ at $22{ }^{\circ} \mathrm{C}$ (drying in an oven for $16 \mathrm{~h}$ at $105^{\circ} \mathrm{C}$ and cooling at $22^{\circ} \mathrm{C}$ for $6 \mathrm{~h}$ ). On the other hand, the shrinkage test was carried out on $25 \times 25 \times 287 \mathrm{~mm}$ specimens for 180 days following the UNE 80-112-89 standard [68].

The statistical analysis of the results was carried out with the statistical package IBM SPSS Statistics v25 @. To know if the results obtained for each property analyzed between the different types of lime mortar produced differed statistically significantly, an analysis was used employing comparison tests. To carry out the complimentary discussion of the results, six samples of each type of mortar were used for each test.

In the discussion of the physical and mechanical properties, mean comparison tests were carried out for independent samples, previously analyzing the fulfillment of the necessary assumptions for the application of parametric tests: (a) normality, (b) homoscedasticity, and (c) independence $[69,70]$. In the cases in which these assumptions are verified, the Student's $t$-test (for two independent samples) or ANOVA (for more than two independent samples) were used. In addition, to understand the comparisons within each group when there were more than two independent samples, the Dunn-Bonferroni test was used [70]. On the other hand, if the necessary assumptions for the parametric tests (Student's $t$-test or ANOVA) were not fulfilled, the analysis was carried out using non-parametric MannWhitney U tests (for two independent samples), and Kruskal-Wallis (for more than two independent samples).

Finally, in the statistical discussion corresponding to the durability tests (resistance to frost and salt crystallization), comparison tests of related samples were used, as they are measurements carried out on the same type of material before and after being subjected to accelerated aging cycles. For this reason, the Student's $t$-test was used for related samples in cases where the necessary assumptions were met for the performance of parametric tests, and, otherwise, the non-parametric test for Wilcoxon related samples was used [69].

\section{Results}

Next, the results obtained for the different tests of mechanical, physical, and durability characterization of the studied mortars are presented.

\subsection{Mechanical Characterization Tests}

Hardened mortars are subjected to a great variety of mechanical stresses depending on their location on site. They experience compression forces when used as joining elements in masonry walls, and they also experience stresses and deformations inherent to the con- 
struction system of which they are a part, such as the case of lime mortars used as coatings that may experience deformations as a consequence of mechanical bending stresses [71].

\subsubsection{Flexural Strength}

The mechanical resistance to bending was determined in standard $4 \times 4 \times 16 \mathrm{~cm}$ specimens that were filled with the mortar in two approximately equal layers, homogenizing each layer of the mixture with 25 strokes in the compactor following the UNE-EN 1015-11:2000/A1:2007 standard [63]. This test is of great relevance for lime mortars that are going to be used in restoration works as coatings, since the ability to withstand deformations without cracks appearing on their surface is greatly important [72]. To carry out the test, a press model AUTETEST 200-10SW was used with a uniform application of the load at a speed between 10-50 N/s. Figure 3 shows the test equipment and the results obtained for flexural strength in each of the mortars studied in this investigation.

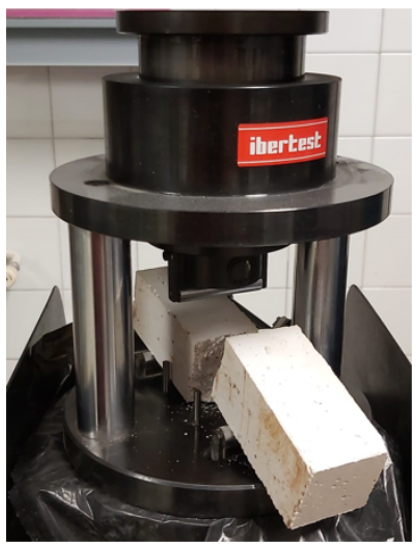

(a)

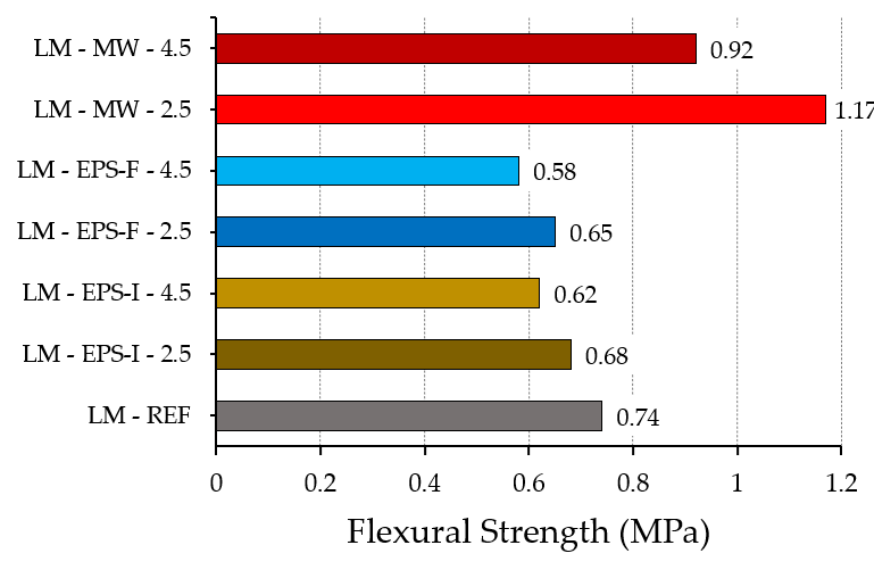

(b)

Figure 3. Flexural strength test. (a) IBERTEST press model AUTOTEST 200-10SW; (b) results obtained for the different batches.

Table 5 shows the results of the statistical discussion of flexural strength by groups of mortars. First, the means and standard deviations (SD) are reflected, together with the confidence interval for the mean with a significance level of $95 \%$. The second part of Table 5 shows the comparison of means between materials and their statistical significance.

Table 5. Statistical analysis for the flexural strength test (MPa) in each group of mortar and its comparison.

\begin{tabular}{ccccccc}
\hline Type & \multicolumn{2}{c}{ Average } & \multicolumn{2}{c}{ SD } & \multicolumn{2}{c}{ Lower/Upper Limits } \\
\hline REF & \multicolumn{2}{c}{0.7422} & \multicolumn{2}{c}{0.04055} & \multicolumn{2}{c}{$[0.7111 ; 0.7734]$} \\
EPS-I & \multicolumn{2}{c}{0.6511} & \multicolumn{2}{c}{0.04484} & \multicolumn{2}{c}{$[0.6288 ; 0.6734]$} \\
EPS-F & \multicolumn{2}{c}{0.6139} & \multicolumn{2}{c}{0.04804} & \multicolumn{2}{c}{$[0.5900 ; 0.6378]$} \\
MW & \multicolumn{2}{c}{1.0456} & \multicolumn{2}{c}{0.14456} & \multicolumn{2}{c}{$0.9737 ; 1.1174]$} \\
\hline \multirow{2}{*}{ Comparison } & REF vs. & REF vs. & REF vs. & EPS-I vs. & EPS-I vs. & EPS-F vs. \\
& EPS-I & EPS-F & MW & EPS-F & MW & MW \\
\hline K & 17.056 & 24.750 & -14.778 & 7.694 & -31.833 & -39.528 \\
$p$-value & 0.135 & 0.006 & 0.289 & 1.000 & 0.000 & 0.000 \\
\hline
\end{tabular}

According to the results obtained and the statistical analysis carried out, it can be seen that the lime mortars made with mineral wool fibers were the ones with the highest flexural strengths (1.0456 MPa on average). This result is because the incorporation of this insulating residue is similar to the effect caused by the incorporation of reinforcing fibers in masonry mortars [73]. On the other hand, mortars reinforced with polystyrene 
fibers were the ones that obtained the worst resistance, the flexural resistance of mortars that incorporated EPS-F being worse, mainly due to the greater particle diameter of this recycled material. In addition, in the case of mortars that incorporated polystyrene residues, it can be seen in Figure 4 that after the test tubes broke there was no good cohesion between the mortar matrix and the recycled EPS insulation spheres. In the comparison of means for flexural strength using the Kruskal-Wallis test, statistical significance was observed with a level of confidence higher than $95 \%$ between the mortars made with MW and the mortars with EPS-F and EPS-I.

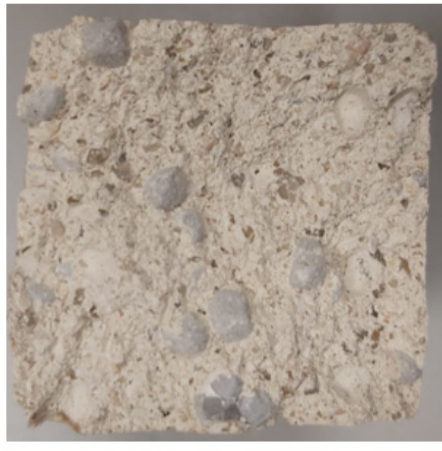

(a)

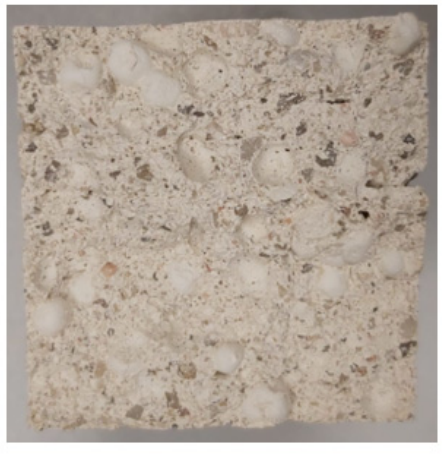

(b)

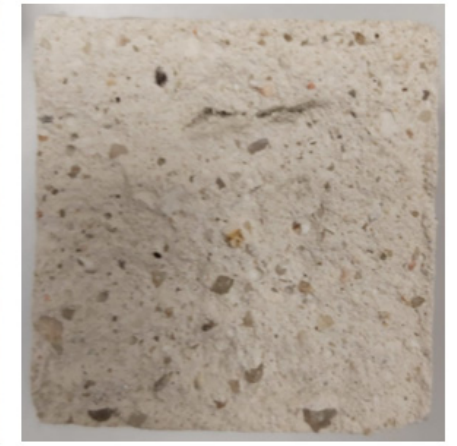

(c)

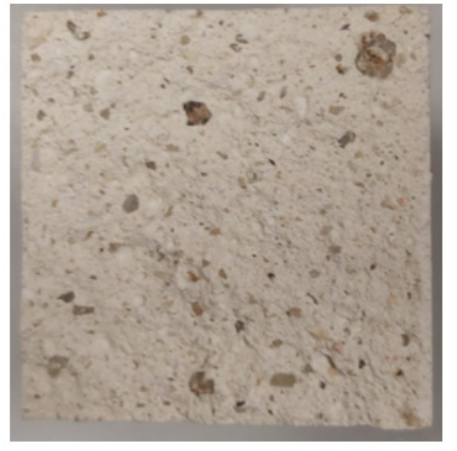

(d)

Figure 4. Breakage of the specimens after the flexural test. (a) LM-EPS-F-2.5; (b) LM-EPS-I-2.5; (c) LM-MW-2.5; (d) LM-REF.

To complete the discussion of these results, a comparison has been made in Table 6 between the flexural strength means of the test tubes that incorporated $2.5 \mathrm{~g}$ of insulating residue, and those that incorporated $4.5 \mathrm{~g}$.

Table 6. Comparison for flexural strength (MPa) between mortars with incorporation of insulating residue.

\begin{tabular}{ccccccc}
\hline Type & Residue (g) & Average & SD & Interval & K & $p$-Value \\
\hline \multirow{2}{*}{ EPS-I } & 2.5 & 0.6833 & 0.03354 & $(0.6576 ; 0.7091)$ & \multirow{2}{*}{16.167} & 1.000 \\
& 4.5 & 0.6189 & 0.02848 & $(0.5970 ; 0.6480)$ & & \\
\hline \multirow{2}{*}{ EPS-F } & 2.5 & 0.6500 & 0.03317 & $(0.6245 ; 0.6755)$ & 15.111 & 1.000 \\
& 4.5 & 0.5778 & 0.02949 & $(0.5551 ; 0.6004)$ & & \multirow{2}{*}{1.000} \\
\hline \multirow{2}{*}{ MW } & 2.5 & 1.1711 & 0.07322 & $(1.1148 ; 1.2274)$ & \multirow{2}{*}{9.000} & \\
& 4.5 & 0.9200 & 0.05979 & $(0.8740 ; 0.9660)$ & & \\
\hline
\end{tabular}

It can be seen in the results shown in Table 6 that in all the test tubes with the incorporation of $2.5 \mathrm{~g}$ of thermal insulation, higher bending strengths were obtained, with the increase in the content of residue incorporated in the matrix impairing this property. However, in no case were these results statistically significant.

\subsubsection{Compressive Strength}

Compressive strength is one of the most decisive parameters when selecting a type of mortar for application on-site. This property depends on the internal cohesion of the mortar and reflects its ability to support loads without disintegrating [74]. In the case of hydraulic lime mortars, it is known that the mechanical resistance to compression increases with time [75], with the binder content, and with the use of continuous granulometry for aggregates [76]. This property is determined by applying a constant load of $1 \mathrm{~mm} / \mathrm{min}$ without acceleration on each of the half-samples obtained after the flexural strength test. In Figure 5, the test method used and the results obtained are shown. 


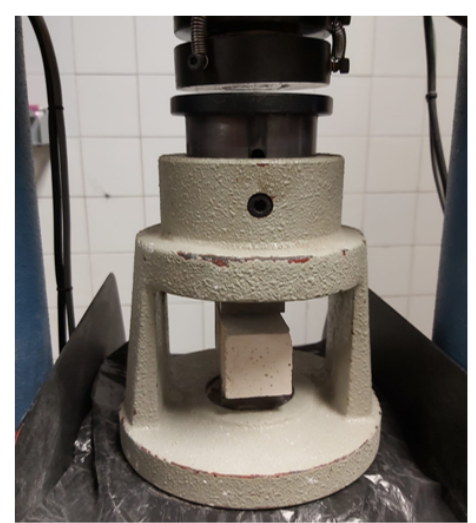

(a)

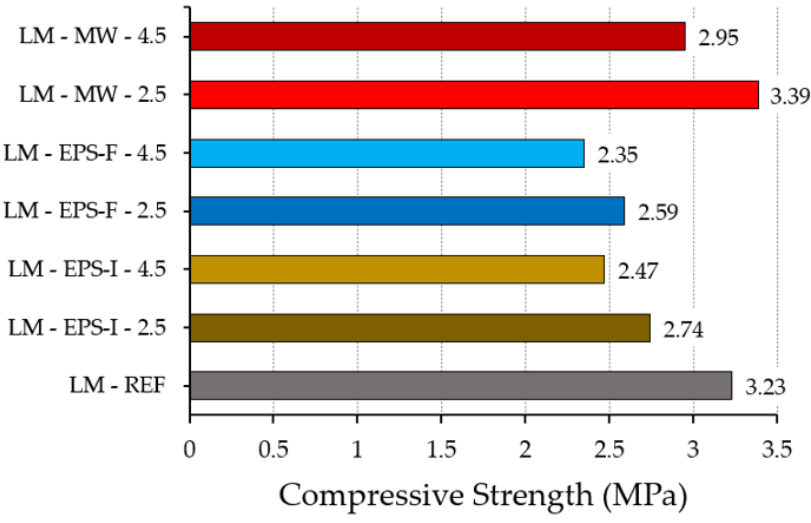

(b)

Figure 5. Compressive strength test. (a) IBERTEST press model AUTETEST 200-10SW; (b) results obtained for the different batches.

Table 7 shows the statistical discussion for the compressive strength in each group of lime mortar produced. To carry out this discussion, the ANOVA and Dunn-Bonferroni tests have been used, as they meet the necessary assumptions for parametric samples.

Table 7. Statistical analysis for the compressive strength test (MPa) for each group of mortar and its comparison.

\begin{tabular}{ccccccc}
\hline Type & \multicolumn{2}{c}{ Average } & \multicolumn{2}{c}{ SD } & \multicolumn{2}{c}{ Lower/Upper Limits } \\
\hline REF & \multicolumn{2}{c}{3.2367} & 0.17313 & $(3.1036 ; 3.3697)$ \\
EPS-I & \multicolumn{2}{c}{2.6061} & \multicolumn{2}{c}{0.18706} & \multicolumn{2}{c}{$(2.5131 ; 2.6991)$} \\
EPS-F & \multicolumn{2}{c}{2.4650} & \multicolumn{2}{c}{0.20624} & \multicolumn{2}{c}{$(2.3642,2.5658)$} \\
MW & \multicolumn{2}{c}{3.1744} & \multicolumn{2}{c}{0.24575} & \multicolumn{2}{c}{$(3.0522 ; 3.2967)$} \\
\hline \multirow{2}{*}{ Comparison } & REF vs. & REF vs. & REF vs. & EPS-I vs. & EPS-I vs. & EPS-F vs. \\
& EPS-I & EPS-F & MW & EPS-F & MW & MW \\
\hline Difference of Means & 0.63056 & 0.77167 & 0.06222 & 0.14111 & -0.56833 & -0.70944 \\
$p$-value & 0.000 & 0.000 & 1.000 & 0.280 & 0.000 & 0.000 \\
\hline
\end{tabular}

As can be seen in Table 7 and Figure 5, the reference mortars without additions were the ones with the highest mechanical resistance to compression (3.2367 MPa), because they presented a more compact matrix and there were no preferred breakage points, as they did not incorporate insulation materials. For this property, it is observed that the addition of mineral wool fibers did not imply an improvement in compressive strength, as has been observed in other previous studies of fiber-reinforced mortars [77]. Even so, mortars with the addition of mineral wool insulation present higher resistance than mortars with the incorporation of expanded polystyrene granules. Thus, the differences in means between mortars with the incorporation of recycled EPS insulation compared to the reference mortars or with the addition of mineral wool were statistically significant for a 95\% confidence level.

Table 8 shows the mean difference in compressive strength for the same type of lime mortar as a function of the insulating residue content.

From the analysis of Table 8, it can be deduced that in the three types of mortar with the incorporation of thermal insulation materials analyzed, those with lower residue content $(2.5 \mathrm{~g}$ ) presented higher mechanical resistance to compression, being, in turn, the differences of means obtained for each of the statistically significant groups for a confidence level of $95 \%$. Both the reference mortar, as well as all mortars incorporating $2.5 \mathrm{~g}$ of thermal insulation, had a resistant class M2.5 at 28 days according to the UNE-EN 998-2: 2012 standard [78]. 
Table 8. Comparison for compressive strength (MPa) between lime mortars with incorporation of thermal insulation residues.

\begin{tabular}{ccccccc}
\hline Type & Residue $(\mathbf{g})$ & Average & SD & Interval & Difference of Means & $p$-Value \\
\hline \multirow{2}{*}{ EPS-I } & 2.5 & 2.7411 & 0.13062 & $(2.6407 ; 2.8415)$ & \multirow{2}{*}{0.27000} & 0.003 \\
& 4.5 & 2.4711 & 0.12762 & $(2.3730 ; 2.5692)$ & 0.23889 & 0.013 \\
\hline \multirow{2}{*}{ EPS-F } & 2.5 & 2.5844 & 0.20653 & $(2.4257 ; 2.7432)$ & \multirow{2}{*}{0.44222} \\
& 4.5 & 2.3456 & 0.11182 & $(2.2596 ; 2.4315)$ & 0.000 \\
\hline \multirow{2}{*}{ MW } & 2.5 & 3.3956 & 0.08918 & $(3.3270 ; 3.4641)$ & $(2.8750 ; 3.0316)$ & \\
& 4.5 & 2.9533 & 0.10186 & & & \\
\hline
\end{tabular}

\subsection{Physical Characterization Tests}

For the physical characterization of the prepared mortars, the following properties were studied: bonding strength, apparent density, Shore D surface hardness, water absorption by capillarity, and thermal conductivity.

\subsubsection{Bonding Strength}

The bonding strength of a mortar can be defined as the property that allows it to remain attached to the ceramic surface that makes up the factory [79]. To determine this property, the UNE-EN 1015-12:2016 standard clarifies that it is necessary to measure the maximum pull-out traction by direct load perpendicular to the surface of the mortar for rendering or plastering that has been applied on certain support [80]. When the adherence is greater, the mechanical energy of the interface between the mortar and the application surface can absorb; this property depends on various factors such as the type of binder, the dosage used, the degree of wetting of the support, and its type or the presence of salts in the masonry factory [81]. The results derived from this test and its method of performance are shown in Figure 6.

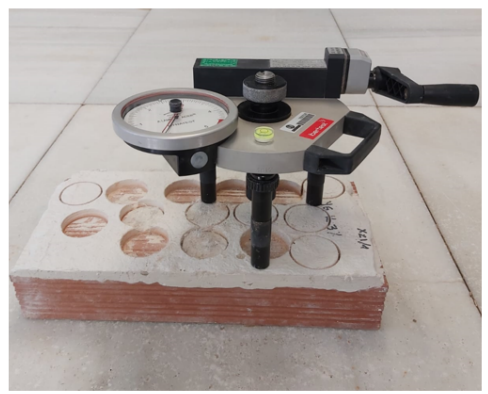

(a)

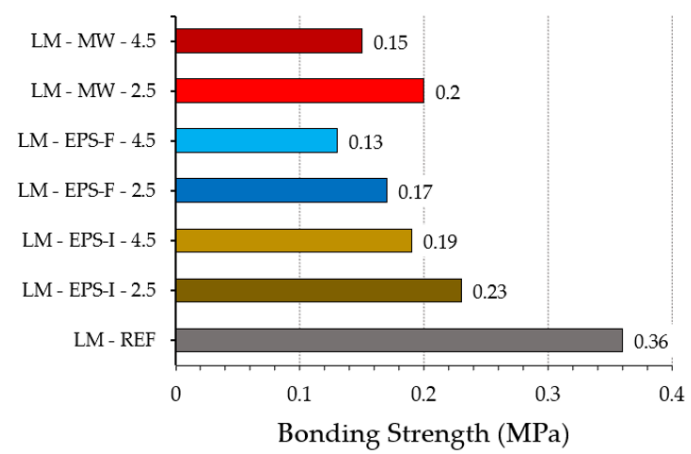

(b)

Figure 6. Bonding strength test. (a) Adhesion measuring equipment and tested sample; (b) results obtained for the different batches.

For the statistical discussion of this property, non-parametric tests were used, as this variable does not comply with the normality assumptions. Table 9 shows the results for each group of mortars and the comparison of means between the different groups using the Kruskal-Wallis test for independent samples.

As shown in Table 9, and in accordance with the results obtained in Figure 6, the highest average adherence was obtained for the reference mortars without additions $(0.3567 \mathrm{MPa})$, the group of mortars with incorporation of EPS-F insulation, and those that had a lower resistance to adhesion $(0.1522 \mathrm{MPa})$. Thus, it can be stated that the incorporation of residues from thermal insulation materials into the matrix of lime mortars decreases its adhesion capacity in ceramic walls. These results follow other previous studies where the resistance to adhesion of masonry mortars incorporates CDW [82]. The results of the 
Kruskal-Wallis mean comparison test can also be seen in the lower part of Table 9, where it can be seen that the difference in means between the reference mortar and each of the mortars with incorporation of thermal insulation (EPS-I, EPS-F, and MW) are statistically significant. The same occurs with the difference in adherence means between the samples that incorporate EPS-I and EPS-F, which turned out to be statistically significant for a confidence level greater than $95 \%$.

Table 9. Statistical analysis for the bonding strength test (MPa) for each group of mortar and its comparison.

\begin{tabular}{|c|c|c|c|c|c|c|}
\hline Type & \multicolumn{2}{|c|}{ Average } & \multicolumn{2}{|c|}{ SD } & \multicolumn{2}{|c|}{ Lower/Upper Limits } \\
\hline REF & \multicolumn{2}{|c|}{0.3567} & \multicolumn{2}{|c|}{0.03428} & \multicolumn{2}{|c|}{$(0.3303 ; 0.3830)$} \\
\hline EPS-I & \multicolumn{2}{|c|}{0.2100} & \multicolumn{2}{|c|}{0.04366} & \multicolumn{2}{|c|}{$(0.1883 ; 0.2317)$} \\
\hline EPS-F & \multicolumn{2}{|c|}{0.1522} & \multicolumn{2}{|c|}{0.03859} & \multicolumn{2}{|c|}{$(0.1330 ; 0.1714)$} \\
\hline MW & \multicolumn{2}{|c|}{0.1750} & \multicolumn{2}{|c|}{0.04120} & \multicolumn{2}{|c|}{$(0.1545 ; 0.1955)$} \\
\hline Comparison & $\begin{array}{l}\text { REF vs. } \\
\text { EPS-I }\end{array}$ & $\begin{array}{l}\text { REF vs. } \\
\text { EPS-F }\end{array}$ & $\begin{array}{c}\text { REF vs. } \\
\text { MW }\end{array}$ & $\begin{array}{c}\text { EPS-I vs. } \\
\text { EPS-F }\end{array}$ & $\begin{array}{c}\text { EPS-I vs. } \\
\text { MW }\end{array}$ & $\begin{array}{c}\text { EPS-F vs. } \\
\text { MW }\end{array}$ \\
\hline K & 20.778 & 40.861 & 32.861 & 20.083 & 12.083 & -8.000 \\
\hline$p$-value & 0.033 & 0.000 & 0.000 & 0.006 & 0.286 & 1.000 \\
\hline
\end{tabular}

For its part, Table 10 shows the difference in adhesion means for the same mortar with different proportions of insulating residue ( $2.5 \mathrm{~g}$ versus $4.5 \mathrm{~g})$.

Table 10. Comparison for the adherence (MPa) in the different mortars with the incorporation of CDW.

\begin{tabular}{|c|c|c|c|c|c|c|}
\hline Type & Residue (g) & Average & SD & Interval & $\mathbf{K}$ & $p$-Value \\
\hline \multirow{2}{*}{ EPS-I } & 2.5 & 0.2322 & 0.02489 & $(0.2131 ; 0.2514)$ & \multirow{2}{*}{14.667} & \multirow{2}{*}{1.000} \\
\hline & 4.5 & 0.1878 & 0.04816 & $(0.1508 ; 0.2248)$ & & \\
\hline \multirow{2}{*}{ EPS-F } & 2.5 & 0.1744 & 0.03468 & $(0.1478 ; 0.2011)$ & \multirow{2}{*}{13.722} & \multirow{2}{*}{1.000} \\
\hline & 4.5 & 0.1300 & 0.02915 & $(0.1076 ; 0.1524)$ & & \\
\hline \multirow{2}{*}{ MW } & 2.5 & 0.2011 & 0.03180 & $(0.1767 ; 0.2256)$ & \multirow{2}{*}{17.833} & \multirow{2}{*}{0.813} \\
\hline & 4.5 & 0.1489 & 0.03257 & $(0.1238 ; 0.1739)$ & & \\
\hline
\end{tabular}

According to the results collected in Table 10, in all cases, a higher adhesion was obtained in mortars that incorporated a lower amount of insulation materials $(2.5 \mathrm{~g})$. However, in this case, the differences between the adhesion mean obtained between the same mortars with a different proportion of thermal insulation in their matrix were not statistically significant in any of the cases.

\subsubsection{Apparent Density}

The density of hardened mortars depends on the individual densities of the different components that make them up. In this sense, one of the greatest advantages of incorporating expanded polystyrene insulation waste is the reduction in final density compared with traditional lime mortars [54]. To determine this property, the recommendations of the UNE-EN 1015-10/A1 [83] standard were followed. Figure 7 shows the hydrostatic balance weighing method and the results derived from this test.

As in the previous case, for the discussion of the results obtained, non-parametric tests were used as this property does not meet the necessary assumptions to perform an ANOVA analysis. Table 11 shows the results obtained for each group of mortars and the comparison of measurements made between the different groups using the Kruskal-Wallis test for independent samples. 


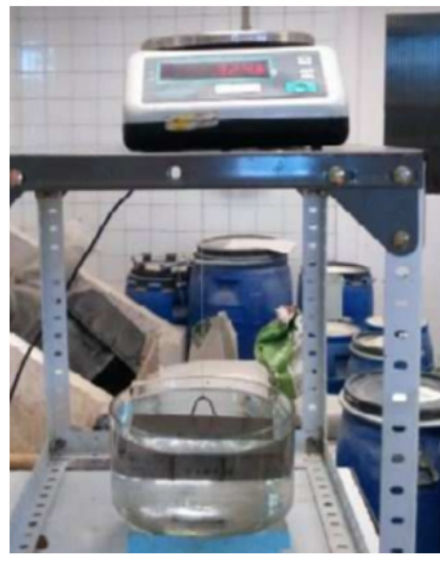

(a)

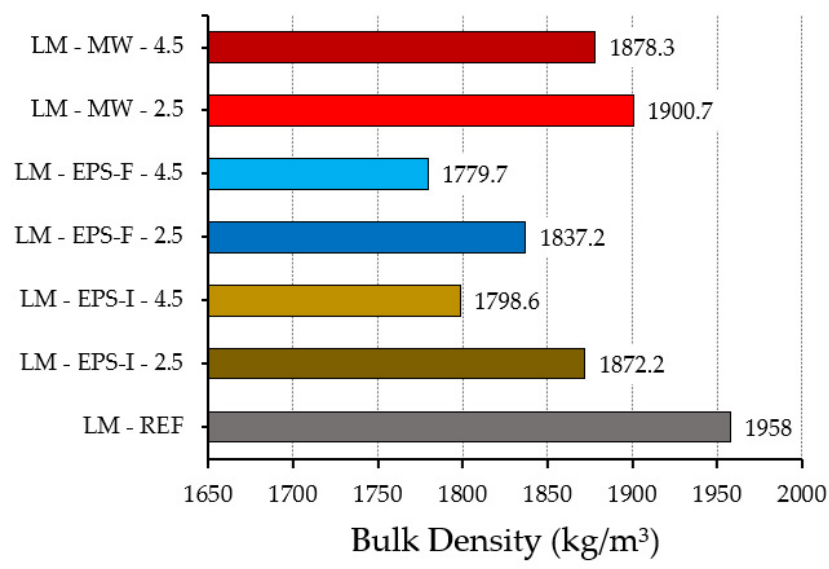

(b)

Figure 7. Apparent density. (a) Hydrostatic balance and taking measurements; (b) results obtained for the different mortars.

Table 11. Statistical analysis for the density test $\left(\mathrm{kg} / \mathrm{m}^{3}\right)$ for each group of mortar and its comparison.

\begin{tabular}{|c|c|c|c|c|c|c|}
\hline Type & \multicolumn{2}{|c|}{ Average } & \multicolumn{2}{|c|}{ SD } & \multicolumn{2}{|c|}{ Lower/Upper Limits } \\
\hline REF & \multicolumn{2}{|c|}{1958.000} & \multicolumn{2}{|c|}{21.7313} & \multicolumn{2}{|c|}{$(1941.296 ; 1974.704)$} \\
\hline EPS-I & \multicolumn{2}{|c|}{1835.389} & \multicolumn{2}{|c|}{44.7005} & \multicolumn{2}{|c|}{$(1813.160 ; 1857.618)$} \\
\hline EPS-F & \multicolumn{2}{|c|}{1808.444} & \multicolumn{2}{|c|}{36.7891} & \multicolumn{2}{|c|}{$(1790.150 ; 1826.739)$} \\
\hline MW & \multicolumn{2}{|c|}{1889.500} & \multicolumn{2}{|c|}{23.8605} & \multicolumn{2}{|c|}{$(1877.634 ; 1901.366)$} \\
\hline Comparison & $\begin{array}{c}\text { REF vs. } \\
\text { EPS-I }\end{array}$ & $\begin{array}{l}\text { REF vs. } \\
\text { EPS-F }\end{array}$ & $\begin{array}{c}\text { REF vs. } \\
\text { MW }\end{array}$ & $\begin{array}{l}\text { EPS-I vs. } \\
\text { EPS-F }\end{array}$ & $\begin{array}{c}\text { EPS-I vs. } \\
\text { MW }\end{array}$ & $\begin{array}{c}\text { EPS-F vs. } \\
\text { MW }\end{array}$ \\
\hline K & 34.583 & 43.194 & 15.944 & 8.611 & -18.639 & -27.250 \\
\hline$p$-value & 0.000 & 0.000 & 0.199 & 0.952 & 0.014 & 0.000 \\
\hline
\end{tabular}

According to the results obtained in Figure 7 and analyzed in Table 11, the incorporation of CDW from thermal insulation materials reduces the final density of hardened lime mortars. More specifically, mortars with the incorporation of expanded polystyrene are those with the greatest reduction in density, with the group of mortars incorporating EPS-F being the lightest $\left(1808.444 \mathrm{~kg} / \mathrm{m}^{3}\right)$. The mean differences found between the reference mortar with EPS-I and EPS-F both turned out to be statistically significant. The same happened in the case of the MW mortar, whose mean differences with both EPS-I and EPS-F were statistically significant for a confidence level greater than $95 \%$. These results are in agreement with those obtained by other authors who have used expanded polystyrene to reduce the density of plaster precast [53].

On the other hand, Table 12 shows the difference in adhesion means for the same mortar with the two proportions of insulating residue used ( $2.5 \mathrm{~g}$ vs. $4.5 \mathrm{~g})$.

Table 12. Comparison for densities $\left(\mathrm{kg} / \mathrm{m}^{3}\right)$ between mortars with incorporation of insulation.

\begin{tabular}{|c|c|c|c|c|c|c|}
\hline Type & Residue (g) & Average & SD & Interval & $\mathbf{K}$ & $p$-Value \\
\hline \multirow{2}{*}{ EPS-I } & 2.5 & 1872.222 & 17.9846 & $(1858.398 ; 1886.046)$ & \multirow{2}{*}{23.167} & \multirow{2}{*}{0.154} \\
\hline & 4.5 & 1798.556 & 29.4962 & $(1775.883 ; 1821.228)$ & & \\
\hline \multirow{2}{*}{ EPS-F } & 2.5 & 1837.222 & 22.8242 & $(1819.678 ; 1854.766)$ & \multirow{2}{*}{15.389} & \multirow{2}{*}{1.000} \\
\hline & 4.5 & 1779.667 & 22.1754 & $(1762.621 ; 1796.712)$ & & \\
\hline \multirow{2}{*}{ MW } & 2.5 & 1900.667 & 22.1303 & $(1883.656 ; 1917.678)$ & \multirow{2}{*}{9.111} & \multirow{2}{*}{1.000} \\
\hline & 4.5 & 1878.333 & 20.9643 & $(1862.219 ; 1894.448)$ & & \\
\hline
\end{tabular}


As can be seen in Table 12, mortars with a higher dosage of insulating residue (4.5 g) obtained a lower density than their counterparts with a lower dosage $(2.5 \mathrm{~g})$. However, the differences in density mean found between the different dosages used were not statistically significant in any of the types of mortars analyzed with the incorporation of these CDWs. This lower density of mortars with the incorporation of $4.5 \mathrm{~g}$ of insulating residues follows the lower mechanical resistance to compression obtained by this type of lime mortar.

\subsubsection{Surface Hardness}

The surface hardness of mortars represents the ability of these materials to resist being scratched by another material on their surface [84]. These types of tests are of great importance in lime mortars that are going to be used as coatings in rehabilitation works since they give us an idea of the resistance to surface wear that they offer over time [85]. To determine the values of this property, a Shore D durometer was used and the indications of the UNE 102042: 2014 [86] standard were adapted, taking, as a result, the average of five random measurements on two flat-parallel lateral faces of the specimens, with $4 \times 4 \times 16 \mathrm{~cm}$ hardened mortar. Figure 8 shows the test method and the results obtained for each of the dosages used.

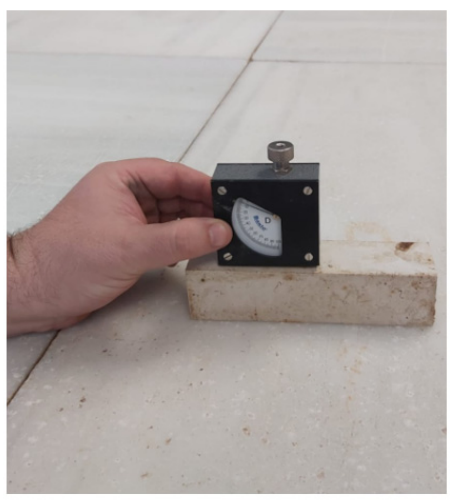

(a)

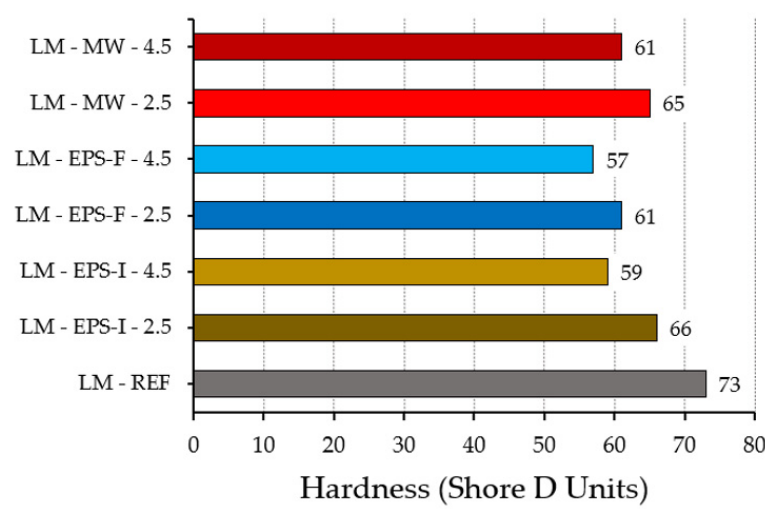

(b)

Figure 8. Surface hardness. (a) Taking measurements with a Shore D Durometer; (b) results obtained for the different mortars.

The analysis of the results of the Shore D hardness tests for each group of mortar is presented in Table 13. Due to the fulfillment of the necessary assumptions for the application of parametric tests, the comparison of means between groups of mortars was carried out employing the ANOVA and Dunn-Bonferroni tests.

Table 13. Statistical analysis for the surface hardness tests (Ud. Shore D) in each group of mortar and its comparison.

\begin{tabular}{ccccccc}
\hline Type & \multicolumn{2}{c}{ Average } & \multicolumn{2}{c}{ SD } & \multicolumn{2}{c}{ Lower/Upper Limits } \\
\hline REF & \multicolumn{2}{c}{72.89} & \multicolumn{2}{c}{3.756} & \multicolumn{2}{c}{$(68 ; 79)$} \\
EPS-I & \multicolumn{2}{c}{62.72} & \multicolumn{2}{c}{5.233} & \multicolumn{2}{c}{$(51 ; 69)$} \\
EPS-F & \multicolumn{2}{c}{58.94} & \multicolumn{2}{c}{6.102} & \multicolumn{2}{c}{$(50 ; 68)$} \\
MW & \multicolumn{2}{c}{63.44} & \multicolumn{2}{c}{4.997} & \multicolumn{2}{c}{$(50)$} \\
\hline \multirow{2}{*}{ Comparison } & REF vs. & REF vs. & REF vs. & EPS-I vs. & EPS-I vs. & EPS-F vs. \\
& EPS-I & EPS-F & MW & EPS-F & MW & MW \\
\hline Difference of Means & 10.167 & 13.944 & 9.444 & 3.778 & -0.722 & -4.500 \\
$p$-value & 0.000 & 0.000 & 0.000 & 0.213 & 1.000 & 0.078 \\
\hline
\end{tabular}

As can be seen in the results shown in Table 13, the reference mortar without additions was the one with the highest Shore D surface hardness. In addition, the differences in means 
between the reference mortar and the other three types of mortar with the incorporation of thermal insulation materials were statistically significant. It should be noted that among the mortars with the incorporation of shredded insulation in their composition, the lime mortars with insulating mineral wool fiber were the ones with the highest surface resistance, and the mortars with the incorporation of expanded polystyrene were the ones with the worst performance against superficial deterioration.

Table 14 shows the comparative analysis of each type of mortar with CDW incorporation according to the amount of residue added in its manufacture.

Table 14. Comparison for the Shore D surface hardness tests between mortars with the incorporation of thermal insulation materials.

\begin{tabular}{|c|c|c|c|c|c|c|}
\hline Type & Residue (g) & Average & SD & Interval & Difference of Means & $p$-Value \\
\hline \multirow{2}{*}{ EPS-I } & 2.5 & 66.22 & 2.489 & $(64.31 ; 68.14)$ & \multirow[b]{2}{*}{7.000} & \multirow{2}{*}{0.065} \\
\hline & 4.5 & 59.22 & 4.944 & $(55.42 ; 63.02)$ & & \\
\hline \multirow{2}{*}{ EPS-F } & 2.5 & 60.67 & 6.325 & $(55.81 ; 65.53)$ & \multirow{2}{*}{3.444} & \multirow{2}{*}{1.000} \\
\hline & 4.5 & 57.22 & 5.696 & $(52.84 ; 61.60)$ & & \\
\hline \multirow{2}{*}{ MW } & 2.5 & 65.44 & 3.283 & $(62.92 ; 67.97)$ & \multirow{2}{*}{4.000} & \multirow{2}{*}{1.000} \\
\hline & 4.5 & 61.44 & 5.769 & $(57.01 ; 65.88)$ & & \\
\hline
\end{tabular}

From the analysis of Table 14, it can be seen that all mortars with the incorporation of $2.5 \mathrm{~g}$ of recycled thermal insulation were those with the highest average surface hardness. However, the difference in means for the counterparts that incorporated $4.5 \mathrm{~g}$ of residue were not statistically significant in any of the cases analyzed.

\subsubsection{Water Absorption by Capillarity}

When working with lime mortars for rehabilitation and their use as coatings, it is essential to know the mechanisms that cause the suction of water by porous materials [87]. This phenomenon is mainly produced by the surface attraction between liquid and solid, which causes a decrease in the free surface energy of the system if a drop of water spreads inside the porous body [88]. The absorption of water by capillarity depends on the diameter of the capillary pore and on how the network of pores inside the mortar are interconnected [89], although the type of aggregate used in its composition, the binder/aggregate ratio, and the difference also influence pressure between the penetrating water and the inner surface [90]. The test method that allows understanding of the coefficient of water absorption by capillarity in mortars is the one described in the UNE-EN 1015-18:2003 [65] standard, using half-rods of mortar submerged in water, one centimeter from the lower face, and fractured for $90 \mathrm{~min}$. Figure 9 shows the test method and the results obtained for the different mortars used.

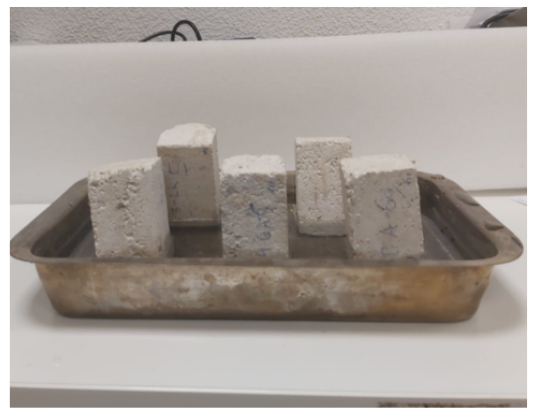

(a)

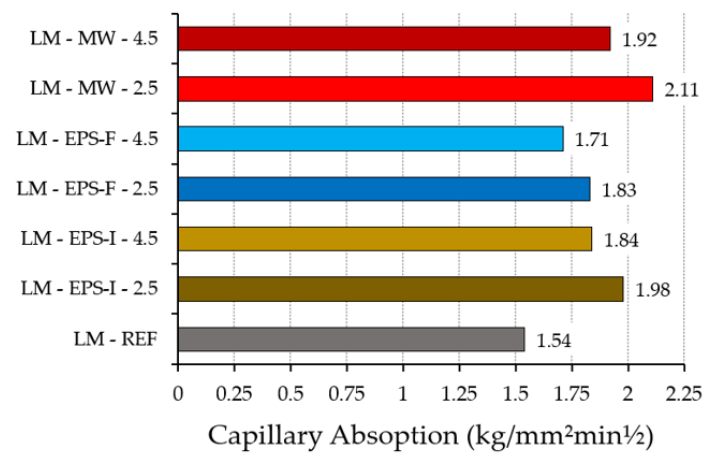

(b)

Figure 9. Water absorption by capillarity. (a) Standardized test according to UNE-EN 1015-18: 2003; (b) results obtained for the different absorption coefficients. 
For the statistical discussion of the results obtained in the water absorption test by capillarity, Table 15 is used. This physical property met the criteria of normality and homoscedasticity required for the application of parametric tests, for this reason, a comparison was used for the mean difference using ANOVA and Dunn-Bonferroni analysis.

Table 15. Statistical analysis for absorption by capillarity $\left(\mathrm{kg} / \mathrm{mm}^{2} \mathrm{~min}^{0.5}\right)$ in each group of mortar and its comparison.

\begin{tabular}{|c|c|c|c|c|c|c|}
\hline Type & \multicolumn{2}{|c|}{ Average } & \multicolumn{2}{|c|}{ SD } & \multicolumn{2}{|c|}{ Lower/Upper Limits } \\
\hline REF & \multicolumn{2}{|c|}{1.5378} & \multicolumn{2}{|c|}{0.16939} & \multicolumn{2}{|c|}{$(1.4076 ; 16680)$} \\
\hline EPS-I & \multicolumn{2}{|c|}{1.9128} & \multicolumn{2}{|c|}{0.18905} & \multicolumn{2}{|c|}{$(1.8188 ; 2.0068)$} \\
\hline EPS-F & \multicolumn{2}{|c|}{1.7739} & \multicolumn{2}{|c|}{0.17790} & \multicolumn{2}{|c|}{$(1.6854 ; 1.8625)$} \\
\hline MW & \multicolumn{2}{|c|}{2.0150} & \multicolumn{2}{|c|}{0.17644} & \multicolumn{2}{|c|}{$(1.9273 ; 2.1027)$} \\
\hline Comparison & $\begin{array}{l}\text { REF vs. } \\
\text { EPS-I }\end{array}$ & $\begin{array}{l}\text { REF vs. } \\
\text { EPS-F }\end{array}$ & $\begin{array}{c}\text { REF vs. } \\
\text { MW }\end{array}$ & $\begin{array}{c}\text { EPS-I vs. } \\
\text { EPS-F }\end{array}$ & $\begin{array}{c}\text { EPS-I vs. } \\
\text { MW }\end{array}$ & $\begin{array}{c}\text { EPS-F vs. } \\
\text { MW }\end{array}$ \\
\hline Difference of Means & -0.37500 & -0.23611 & -0.47722 & 0.13889 & -0.10222 & -0.24111 \\
\hline$p$-value & 0.000 & 0.013 & 0.000 & 0.143 & 0.001 & 0.000 \\
\hline
\end{tabular}

As can be seen in Table 15, the reference dosage is the one that shows the best behavior to prevent pathologies derived from the absorption of water by capillarity, since it has the lowest absorption coefficient $\left(1.5378 \mathrm{~kg} / \mathrm{mm}^{2} \mathrm{~min}^{0.5}\right)$. For their part, the dosages with the incorporation of mineral wool fiber thermal insulation materials were the ones that presented the worst results for this property, having an average water absorption by capillarity higher than that of the other mortars included in this study. All the analyzed mean differences turned out to be statistically significant for a confidence level greater than 95\%, except for the comparison between EPS-I and EPS-F, which returned a non-statistically significant difference.

Table 16 shows the results obtained for the comparison between mortars with the incorporation of thermal insulation based on residue content.

Table 16. Comparison for the absorption by capillarity $\left(\mathrm{kg} / \mathrm{mm}^{2} \mathrm{~min}^{0.5}\right)$ between mortars with incorporation of thermal insulation materials.

\begin{tabular}{|c|c|c|c|c|c|c|}
\hline Type & Residue (g) & Average & SD & Interval & Difference of Means & $p$-Value \\
\hline \multirow{2}{*}{ EPS-I } & 2.5 & 1.8944 & 0.17650 & $(1.8488 ; 2.1201)$ & \multirow{2}{*}{0.14333} & \multirow{2}{*}{1.000} \\
\hline & 4.5 & 1.8411 & 0.18231 & $(1.7010 ; 1.9812)$ & & \\
\hline \multirow{2}{*}{ EPS-F } & 2.5 & 1.8333 & 0.14925 & $(1.7186 ; 1.9481)$ & \multirow{2}{*}{0.11889} & \multirow{2}{*}{1.000} \\
\hline & 4.5 & 1.7144 & 0.19243 & $(1.5665 ; 1.8624)$ & & \\
\hline \multirow{2}{*}{ MW } & 2.5 & 2.1122 & 0.15959 & $(1.9895 ; 2.2349)$ & \multirow{2}{*}{0.19444} & \multirow{2}{*}{0.360} \\
\hline & 4.5 & 1.9178 & 0.13935 & $(1.8107 ; 2.0249)$ & & \\
\hline
\end{tabular}

In all the cases analyzed in Table 16, the mortars with the highest proportion of thermal insulation material in their composition ( $4.5 \mathrm{~g}$ ) presented less water absorption by capillarity, which may be due to the lower compactness of these mortars [91]. However, as reflected in the $p$-value collected in Table 16, the mean difference with the mortars that incorporated $2.5 \mathrm{~g}$ of insulating residue could not be considered statistically significant in any of the tires analyzed.

\subsubsection{Thermal Conductivity}

The building sector is moving towards an efficient use of natural resources and a reduction in the environmental impact generated by industrial activity; thereby, the sector is committed to the design of new eco-efficient materials that minimize energy consumption and incorporate CDW in composition [92]. In this sense, the study of the thermal performance of lime mortars for use in rehabilitation and restoration works is oriented 
towards the general idea of using durable materials that improve the starting conditions of the initial construction system [93]. For this reason, one of the greatest possibilities offered by the use of thermal insulation materials in the manufacture of this type of mortar is the reduction of the thermal conductivity of the materials made with these raw materials [94]. For this test, the standard UNE-EN 12667: 2002 [95] was used as a reference.

Figure 10 shows the equipment used to determine the thermal conductivity through the heat flow that passed through the mortar specimen, and the results obtained for this physical property. In addition, Table 17 presents the analysis of the results for each mortar group using the ANOVA and Dunn-Bonferroni tests.

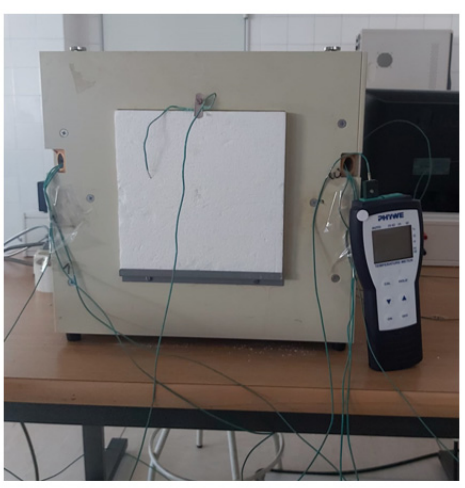

(a)

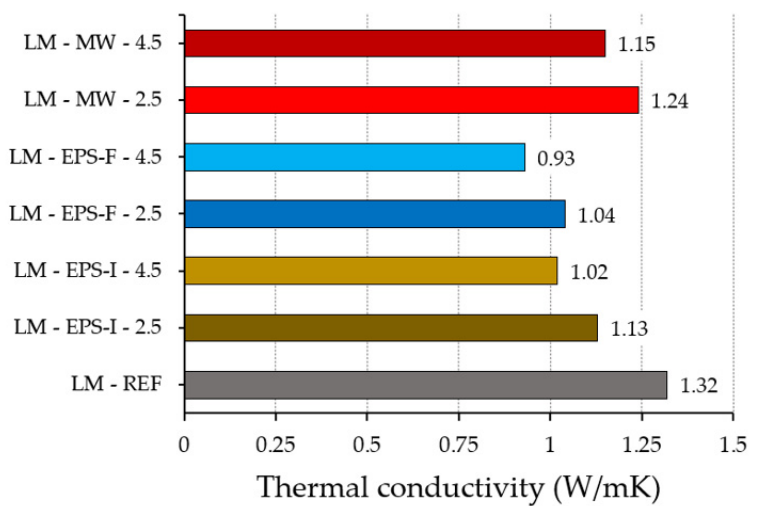

(b)

Figure 10. Thermal conductivity. (a) Test equipment; (b) results obtained for the different mortars with incorporation of thermal insulation material.

Table 17. Statistical analysis for thermal Conductivity $(\mathrm{W} / \mathrm{mK})$ in each group of mortar and its comparison.

\begin{tabular}{ccccccc}
\hline Type & \multicolumn{2}{c}{ Average } & \multicolumn{2}{c}{ SD } & \multicolumn{2}{c}{ Lower/Upper Limits } \\
\hline REF & \multicolumn{2}{c}{1.3200} & 0.07382 & $(1.2633 ; 1.3767)$ \\
EPS-I & \multicolumn{2}{c}{1.0750} & \multicolumn{2}{c}{0.07876} & \multicolumn{2}{c}{$(1.0358 ; 1.1142)$} \\
EPS-F & \multicolumn{2}{c}{0.9833} & \multicolumn{2}{c}{0.10210} & \multicolumn{2}{c}{$(0.9326 ; 1.0341)$} \\
MW & \multicolumn{2}{c}{1.1956} & \multicolumn{2}{c}{0.08740} & \multicolumn{2}{c}{$(1.1521 ; 1.2390)$} \\
\hline \multirow{2}{*}{ Comparison } & REF vs. & REF vs. & REF vs. & EPS-I vs. & EPS-I vs. & EPS-F vs. \\
& EPS-I & EPS-F & MW & EPS-F & MW & MW \\
\hline Difference of Means & 0.24500 & 0.33667 & 0.12444 & 0.09167 & -0.12056 & -0.21222 \\
$p$-value & 0.000 & 0.000 & 0.006 & 0.016 & 0.001 & 0.000 \\
\hline
\end{tabular}

According to the results shown in Table 17, mortars with the incorporation of thermal insulation material reduce thermal conductivity compared to traditional lime mortars. The incorporation of EPS-F residue is the one that presents the best results on average $(0.9833 \mathrm{~W} / \mathrm{mK})$, followed by the other residue of expanded polystyrene (EPS-I, $1.075 \mathrm{~W} / \mathrm{mK})$. Furthermore, when carrying out the mean comparison study, it was obtained that all the mean differences found in each of the comparisons were statistically significant for confidence levels above $95 \%$.

Table 18 shows an exhaustive analysis of the results obtained for the comparison between mortars with the incorporation of thermal insulation as a function of residue content.

From the analysis of Table 19, it can be deduced that in the three types of mortars with the incorporation of CDW studied in this work, the thermal conductivity was reduced in the samples that contained a greater amount of thermal insulation material. Additionally, the difference in means obtained between mortars with the incorporation of foam was statistically significant. This does not happen in the same way with mortars made with 
mineral wool fiber, where the differences in the mean thermal conductivity between the mix containing $2.5 \mathrm{~g}$ and the one containing $4.5 \mathrm{~g}$ were not statistically significant.

Table 18. Comparison for thermal conductivity $(\mathrm{W} / \mathrm{mK})$ between mortars with incorporation of the different thermal insulation materials.

\begin{tabular}{|c|c|c|c|c|c|c|}
\hline Type & Residue (g) & Average & SD & Interval & Difference of Means & $p$-Value \\
\hline \multirow{2}{*}{ EPS-I } & 2.5 & 1.1311 & 0.05231 & $(1.0909 ; 1.1713)$ & \multirow[b]{2}{*}{0.11222} & \multirow[b]{2}{*}{0.046} \\
\hline & 4.5 & 1.0189 & 0.05798 & $(0.9743 ; 1.0635)$ & & \\
\hline \multirow[b]{2}{*}{ EPS-F } & 2.5 & 1.0400 & 0.09042 & $(0.9705 ; 1.1095)$ & \multirow[b]{2}{*}{0.11333} & \multirow[b]{2}{*}{0.042} \\
\hline & 4.5 & 0.9267 & 0.08216 & $(0.8635 ; 0.9898)$ & & \\
\hline \multirow{2}{*}{ MW } & 2.5 & 1.2389 & 0.07474 & $(1.1814 ; 1.2963)$ & \multirow{2}{*}{0.08667} & \multirow{2}{*}{0.340} \\
\hline & 4.5 & 1.1522 & 0.08012 & $(1.0906 ; 1.2138)$ & & \\
\hline
\end{tabular}

Table 19. Analysis of flexural strength in the freezing test by Student's $t$-test.

\begin{tabular}{|c|c|c|c|c|c|c|}
\hline Mortar & Test & Average & SD & Confidence Interval * & $\mathbf{t}$ & $p$-Value \\
\hline \multirow{2}{*}{ LM-REF } & Not cycles & 1.7467 & 0.10886 & $(1.6630 ; 1.8303)$ & \multirow{2}{*}{4.083} & \multirow{2}{*}{0.004} \\
\hline & Cycles & 1.5578 & 0.09365 & $(1.4858 ; 1.6298)$ & & \\
\hline \multirow{2}{*}{ LM-EPS-I-2.5 } & Not cycles & 1.4622 & 0.09897 & $(1.3861 ; 1.5383)$ & \multirow{2}{*}{5.082} & \multirow{2}{*}{0.001} \\
\hline & Cycles & 1.2689 & 0.08838 & $(1.2010 ; 1.3368)$ & & \\
\hline \multirow{2}{*}{ LM-EPS-I-4.5 } & Not cycles & 1.2489 & 0.08507 & $(1.1835 ; 1.3143)$ & \multirow{2}{*}{5.580} & \multirow{2}{*}{0.001} \\
\hline & Cycles & 1.0633 & 0.08031 & $(1.0016 ; 1.1251)$ & & \\
\hline \multirow{2}{*}{ LM-EPS-F-2.5 } & Not cycles & 1.3956 & 0.16607 & $(1.2679 ; 1.5232)$ & \multirow{2}{*}{2.221} & \multirow{2}{*}{0.057} \\
\hline & Cycles & 1.1811 & 0.13923 & $(1.0741 ; 1.2881)$ & & \\
\hline \multirow{2}{*}{ LM-EPS-F-4.5 } & Not cycles & 1.1267 & 0.09695 & $(1.0521 ; 1.2012)$ & \multirow{2}{*}{9.655} & \multirow{2}{*}{0.000} \\
\hline & Cycles & 0.9722 & 0.09576 & $(0.8986 ; 1.0458)$ & & \\
\hline \multirow[b]{2}{*}{ LM-MW-2.5 } & Not cycles & 2.0467 & 0.14874 & $(1.9323 ; 2.1610)$ & \multirow[b]{2}{*}{4.659} & \multirow[b]{2}{*}{0.002} \\
\hline & Cycles & 1.7911 & 0.09185 & $(1.7205 ; 1.8617)$ & & \\
\hline \multirow{2}{*}{ LM-MW-4.5 } & Not cycles & 1.8578 & 0.13160 & $(1.7566 ; 1.9589)$ & \multirow{2}{*}{3.461} & \multirow{2}{*}{0.009} \\
\hline & Cycles & 1.6211 & 0.10325 & $(1.5417 ; 1.7005)$ & & \\
\hline
\end{tabular}

\subsection{Durability Tests}

We understand the durability of mortars as their ability to withstand the physicochemical conditions to which they are exposed throughout their useful life, and that in some way may cause their deterioration. In this sense, durability tests are of vital importance when it comes to knowing the behavior of mortars over time. For this reason, this section contains three tests that evaluate the durability of the processed samples: freezing; salt crystallization; and shrinkage.

\subsubsection{Freeze-Thaw Test}

The freeze-thaw test evaluates the suitability of the mortars that are going to be used outdoors in climates that reach temperatures below $0{ }^{\circ} \mathrm{C}$, determining the loss of mass and mechanical resistance that occurs in the samples when subjected to constant dimensional changes as a consequence of intermittent icing and thawing inside [96]. To carry out this test, the adopted recommendations of the UNE-EN 12371 standard for natural stone [66] were followed. The results shown in Figure 11 show the variations produced in flexural strength and loss of mass after the test. 


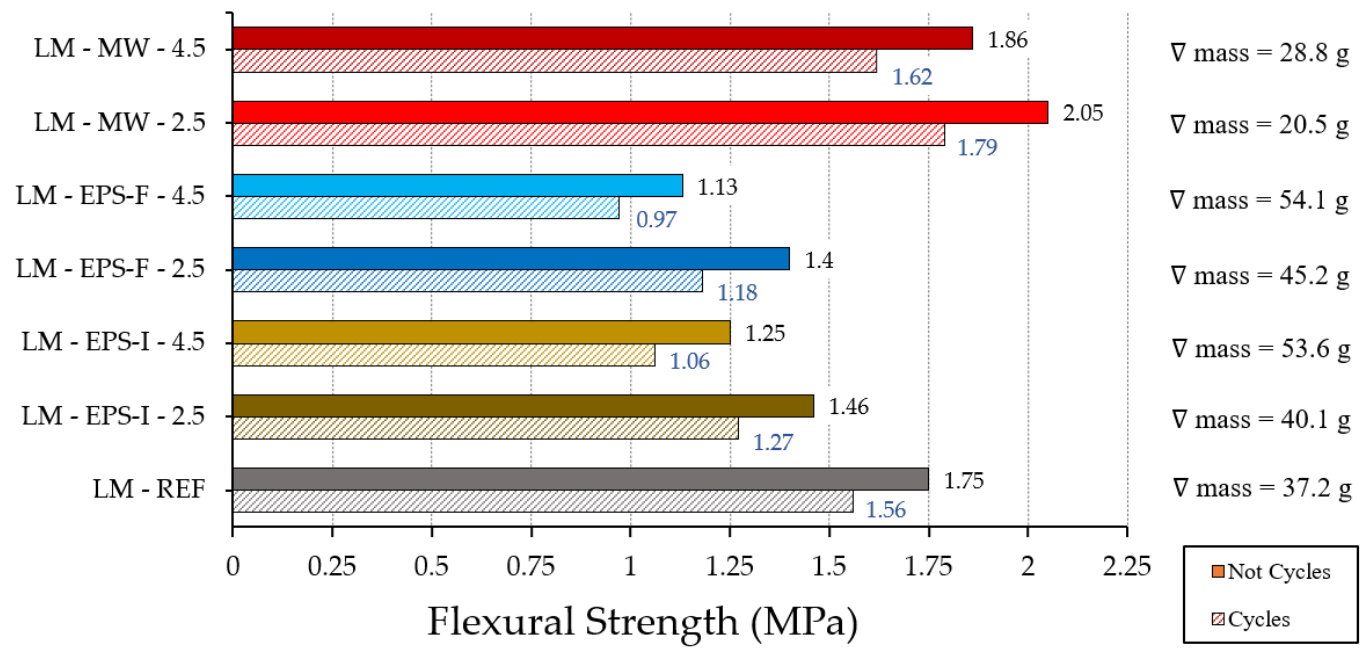

Figure 11. Results of the freeze-thaw test. Flexural strength of samples subjected to freezing cycles (striped stripes) and reference samples (solid stripes), including loss of mass.

As can be seen in Figure 11, lime mortars that incorporated $4.5 \mathrm{~g}$ of recycled insulating material had lower flexural strengths and greater loss of mass after the test than mortars that contained $2.5 \mathrm{~g}$ of insulation in their composition. Furthermore, it can be seen that the mortars that incorporated polystyrene insulation had a worse performance than the reference mortars without additions, which resulted in a high loss of mass after the test, together with a strong decrease in their mechanical resistance to bending. However, it can be seen that mortars that incorporated mineral wool insulation had greater stability and experienced less degradation when subjected to freeze-thaw cycles. These results are in agreement with those obtained by other authors who have studied the beneficial effect of the incorporation of fibers in the mortar matrix to increase the durability of these construction materials [97].

Table 19 shows the results derived from the statistical comparison between the flexural strengths obtained for the samples subjected to durability cycles versus the reference samples tested at the same age. As they were related samples and complied with the necessary assumptions, the Student's $t$-test was applied for related samples.

In Table 19, it can be seen that in all the cases studied, except in the sample LM-EPS-F2.5 , the difference in means between the flexural strength in the reference specimens and the specimens subjected to freeze-thaw cycles were statistically significant. In addition, it is observed that, in all cases, the mean flexural strength was greater in the specimens with no cycles, as expected, with the sample LM-MW-2.5 being the one with the highest flexural strength, and therefore the one with the best performance presented before this durability test.

\subsubsection{Salt Crystallization}

The crystallization of salts, of different nature and formation depending on the environmental parameters, is one of the most frequent and aggressive deterioration mechanisms that construction materials can suffer, especially if they are porous [98]. Although there is no specific standard to carry out this test on mortars, the UNE-EN 12370 standard for application to the natural stone was adapted [67]. This is a test that generally causes intense deterioration, since once the water from the solution evaporates and the salt crystallizes, it remains lodged inside the mortar and occupies a volume 17 times greater than in solution [99]. The results of the flexural test on the mortar samples with and without crystallization cycles are shown in Figure 12, together with the loss of mass of the cycled specimens. 


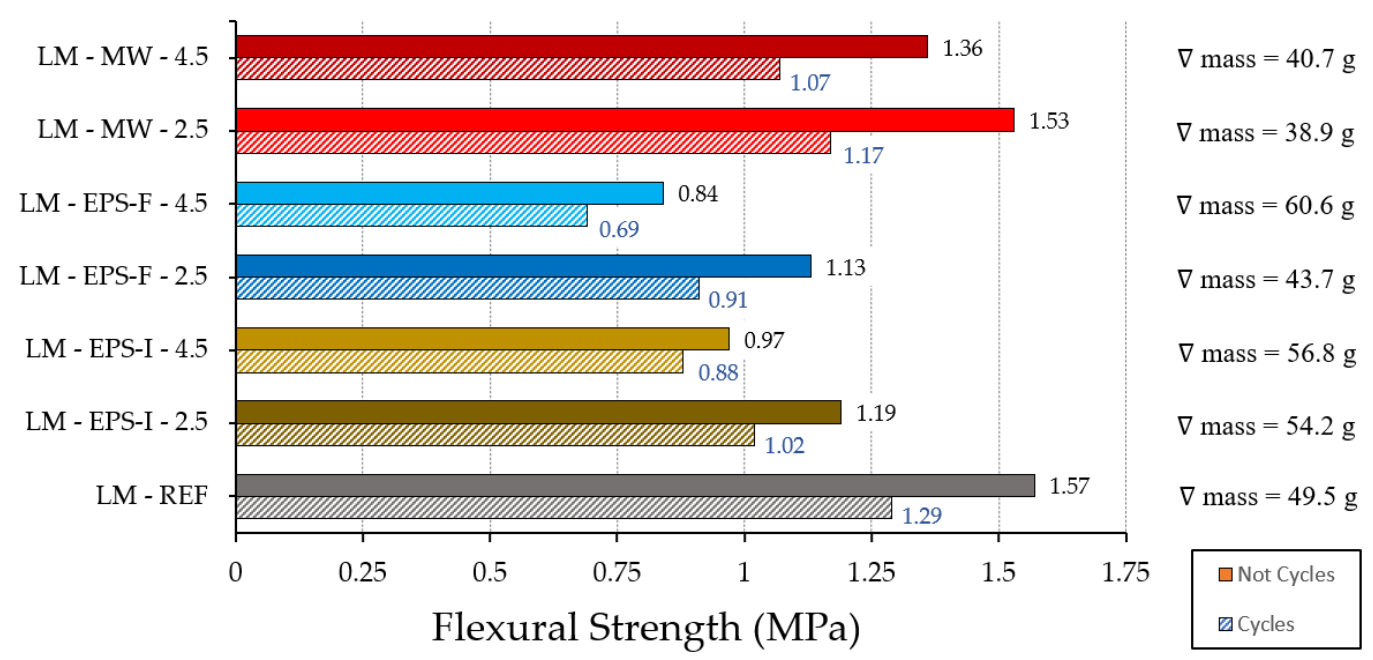

Figure 12. Results of the salt crystallization test. Flexural strength of cycled samples (scratched stripes) and reference samples (solid stripes), including loss of mass.

In Figure 12, it can be seen that the deterioration suffered by the mortar specimens after having been subjected to the salt crystallization test was greater than that obtained in the freezing test. It can be seen that there was a strong loss of mass in all the samples subjected to crystallization cycles, the loss of mass being greater in mortars that incorporated polystyrene insulation materials in their composition. It is also observed that the samples that contained a higher content of insulating residue ( $4.5 \mathrm{~g}$ ) showed worse performance in this test, and lower bending strengths than the samples with less incorporation of residue $(2.5 \mathrm{~g})$. In addition, as was the case with the freezing test, mortars with the incorporation of mineral wool residue presented less mass loss than the rest when subjected to crystallization cycles, even reaching mechanical bending strengths close to that of lime mortars without additions.

Next, Table 20 presents the results derived from the statistical comparison between the flexural strengths obtained for samples subjected to salt crystallization cycles versus the reference samples tested at the same age. As was the case for the freezing test, these are related samples, and met the necessary assumptions to apply the Student's $t$-test.

Table 20. Analysis for flexural strength in the salt crystallization test by Student's $t$ test.

\begin{tabular}{|c|c|c|c|c|c|c|}
\hline Mortar & Test & Average & SD & Confidence Interval * & $\mathbf{t}$ & $p$-Value \\
\hline \multirow[b]{2}{*}{ LM-REF } & Not cycles & 1.5744 & 0.11126 & $(1.4889 ; 1.6600)$ & \multirow{2}{*}{8.131} & \multirow[b]{2}{*}{0.000} \\
\hline & Cycles & 1.2856 & 0.10760 & $(1.2028 ; 1.3683)$ & & \\
\hline \multirow{2}{*}{ LM-EPS-I-2.5 } & Not cycles & 1.1900 & 0.07550 & $(1.1320 ; 1.2480)$ & \multirow{2}{*}{2.786} & \multirow{2}{*}{0.024} \\
\hline & Cycles & 1.0244 & 0.11780 & $(0.9339 ; 1.1150)$ & & \\
\hline \multirow{2}{*}{ LM-EPS-I-4.5 } & Not cycles & 0.9733 & 0.11011 & $(0.8887 ; 1.0580)$ & \multirow{2}{*}{1.900} & \multirow{2}{*}{0.094} \\
\hline & Cycles & 0.8811 & 0.08950 & $(0.8123 ; 0.9499)$ & & \\
\hline \multirow{2}{*}{ LM-EPS-F-2.5 } & Not cycles & 1.1278 & 0.06140 & $(1.0806 ; 1.1750)$ & \multirow{2}{*}{4.217} & \multirow{2}{*}{0.003} \\
\hline & Cycles & 0.9133 & 0.11045 & $(0.8284 ; 0.9982)$ & & \\
\hline \multirow{2}{*}{ LM-EPS-F-4.5 } & Not cycles & 0.8411 & 0.11656 & $(0.7515 ; 0.9307)$ & \multirow{2}{*}{1.637} & \multirow{2}{*}{0.140} \\
\hline & Cycles & 0.6822 & 0.26570 & $(0.4880 ; 0.8965)$ & & \\
\hline \multirow{2}{*}{ LM-MW-2.5 } & Not cycles & 1.5311 & 0.09880 & $(1.4552 ; 1.6071)$ & \multirow{2}{*}{7.197} & \multirow{2}{*}{0.000} \\
\hline & Cycles & 1.1667 & 0.08818 & $(1.0989 ; 1.2344)$ & & \\
\hline \multirow{2}{*}{ LM-MW-4.5 } & Not cycles & 1.3600 & 0.12550 & $(1.2635 ; 1.4565)$ & \multirow{2}{*}{3.886} & \multirow{2}{*}{0.005} \\
\hline & Cycles & 1.0700 & 0.16432 & $(0.9437 ; 1.1963)$ & & \\
\hline
\end{tabular}

\footnotetext{
* Confidence intervals for the mean have been constructed for $\alpha=0.05$
} 
As can be seen in Table 20, except for the mortars with the incorporation of $4.5 \mathrm{~g}$ of polystyrene, all the tested samples presented a significant mean difference between the flexural strength of the reference specimens and those subjected to crystallization cycles. It can be seen that, in all cases, the specimens without cycles that did not suffered deterioration or loss of mass showed greater resistance to bending and, as was the case with the freezing test, the LM-MW-2.5 dosage was the sample with the incorporation of insulation material that had the best performance when subjected to this durability test. It should be noted that these types of tests are of special relevance for the preparation of restoration mortars that are to be applied in urban environments, where it has been verified that run-off water can have a high salt content that is detrimental to the lime mortars applied outdoors [100].

\subsubsection{Shrinkage}

Shrinkage is the process of volumetric contraction that mortars undergo during their setting process [101]. This phenomenon has two distinct origins, which can lead to two types of shrinkage: thermal or hydraulic. In any case, it is a phenomenon that directly affects the durability of mortars, generating internal stresses that, depending on the modulus of elasticity and the deformation capacity of the mortar, can range from volume reduction to cracking of the samples. [102]. For this reason, it was decided that we would study the shrinkage produced in the lime mortars made for 180 days, using $25 \times 25 \times 287 \mathrm{~mm}$ samples. The results derived from this trial are shown in Figure 13.

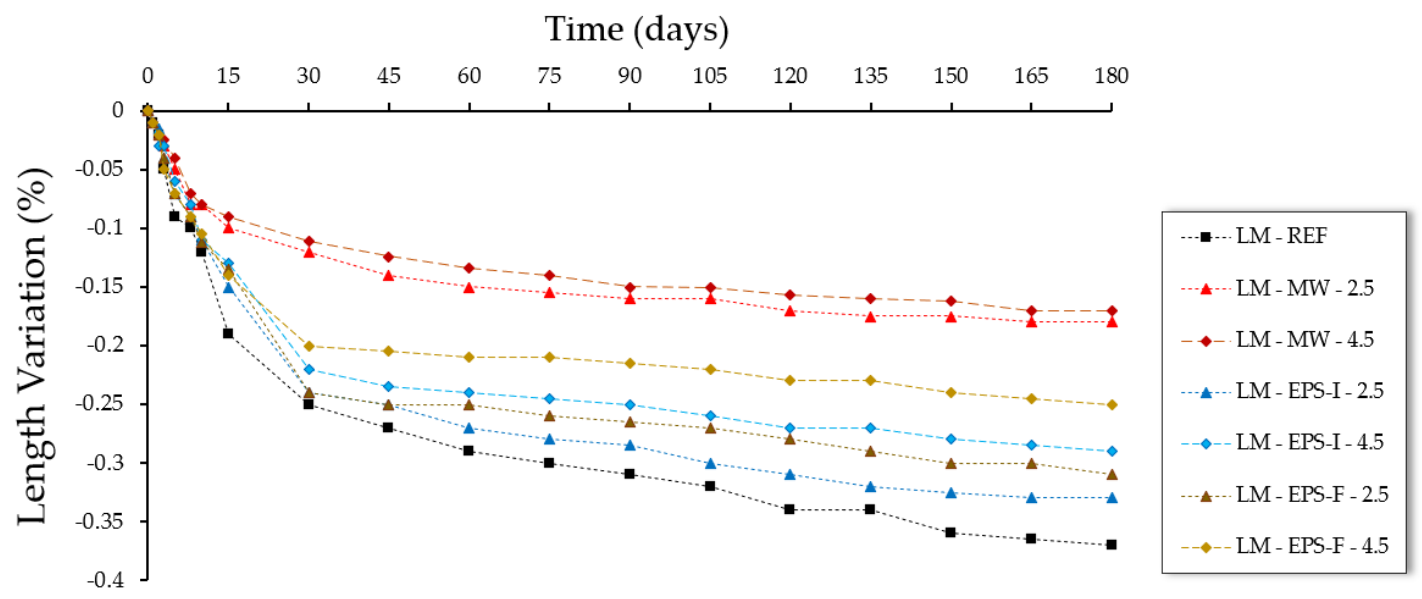

Figure 13. Shrinkage evolution. Length variation (\%) during setting time (days).

The results obtained in Figure 13 show that the incorporation of the different isolates from CDW used in this investigation reduced the shrinkage of the lime mortars. In the case of the samples with the incorporation of EPS, it can be seen that the incorporation of an amount of $4.5 \mathrm{~g}$ decreased the shrinkage more than in the case of mortars that contained $2.5 \mathrm{~g}$ of this material, with the expanded polystyrene specially indicated for use, presenting better results on facades. However, and in agreement with other previous studies [103], the incorporation of mineral wool fibers was the one that reported greater dimensional stability for mortars.

\section{Conclusions}

This research delves into the possibility of incorporating waste from three different types of thermal insulation materials (EPS-F, EPS-I, and MW) as raw material in the manufacture of lime mortars. In this way, this research is intended to assist in moving towards a more sustainable management of construction and demolition waste, exploring the many possibilities offered by this type of waste to improve the technical performance of the lime mortars traditionally used in restoration and rehabilitation works. 
In the mechanical characterization of mortars, it was possible to observe the beneficial effects of the incorporation of mineral wool insulation fibers in the production of these materials. In this way, an increase in the flexural strength of lime mortars was observed with the incorporation of this residue, compared with the reference mortars, not observing large differences between the two in compressive strengths. However, the incorporation of the expanded polystyrene granular residue was detrimental to the mechanical strength of the mortars, regardless of the residue content and the type of polystyrene. Finally, it was possible to observe that the best results were obtained in mortars with the incorporation of $2.5 \mathrm{~g}$ of residue, compared to mortars with $4.5 \mathrm{~g}$ of residue.

Regarding the physical characterization of the prepared mortars, both the Shore D surface hardness and the adhesion on ceramic surfaces were negatively affected as a result of the incorporation of these insulating residues. On the other hand, the incorporation of expanded polystyrene materials made it possible to reduce the final density of the mortars and their thermal conductivity, with mortars that incorporated $4.5 \mathrm{~g}$ of this type of residue in their composition having a better performance, and the prepared mortars having better characteristics with EPS-F. Finally, the absorption of water by capillarity was negatively affected, since in all the analyzed mortars higher absorption coefficients were obtained than in the reference lime mortars.

Finally, durability tests showed that mortars made with this type of thermal insulation waste can be designed for use in exterior cladding. Specifically, after freeze-thaw cycles and salt crystallization, it was possible to verify that lime mortars with the incorporation of mineral wool residue had good stability and better resistance after accelerated aging tests than traditional mortars. In all cases, it was observed that the content of $4.5 \mathrm{~g}$ of residue reduced the final mechanical strength of the material and led to a greater loss of mass after durability tests, compared with samples containing $2.5 \mathrm{~g}$ of thermal insulation materials. Furthermore, both in the freezing test and in the salt crystallization test, the mortars with the incorporation of EPS residue were the ones that showed the worst results. In the end, the shrinkage test showed the beneficial effect of incorporating these residues in the lime mortar matrix to provide them with greater dimensional stability, obtaining the best results after incorporating mineral wool fiber residues.

Author Contributions: Conceptualization, D.F. and E.Y.; methodology, D.F. and A.Z.; software, E.Y; validation, D.F., E.Y. and C.M.; formal analysis, D.F.; investigation, A.Z., D.F. and E.Y.; resources, M.K.-K.; data curation, D.F. and E.Y.; writing-original draft preparation, D.F.; writing-review and editing, E.Y.; visualization, C.M.; supervision, C.M. and M.K.-K.; project administration, C.M.; funding acquisition, D.F. and M.K.-K. All authors have read and agreed to the published version of the manuscript.

Funding: This research received no external funding.

Institutional Review Board Statement: Not applicable.

Informed Consent Statement: Not applicable.

Data Availability Statement: Not applicable.

Acknowledgments: The authors would like to acknowledge the collaboration of the company URSA Ibérica Aislantes, SA, through the project P2054090068 “Thermo-acoustic solutions in housing renovation, simulation, and monitoring", which has served as a support and initiative framework for the realization of this research. They also want to thank the collaboration of Irantzu Recalde-Esnoz, who has helped enormously in the statistical treatment of the data.

Conflicts of Interest: The authors declare no conflict of interest.

\section{References}

1. D'Agostino, D.; Tsemekidi Tzeiranaki, S.; Zangheri, P.; Bertoldi, P. Assessing Nearly Zero Energy Buildings (NZEBs) development in Europe. Energy Strategy Rev. 2021, 36, 100680. [CrossRef]

2. Porras-Amores, C.; Martin Garcia, P.; Villoria Sáez, P.; del Rio Merino, M.; Vitielo, V. Assessing the Energy Efficiency Potential of Recycled Materials with Construction and Demolition Waste: A Spanish Case Study. Appl. Sci. 2021, 11, 7809. [CrossRef] 
3. Cerezo-Narváez, A.; Piñero-Vilela, J.M.; Rodríguez-Jara, E.A.; Otero-Matero, M.; Pastor-Fernández, A.; Ballesteros-Pérez, P. Energy, emissions and economic impact of the new nZEB regulatory framework on residential buildings renovation: Case study in southern Spain. J. Build. Eng. 2021, 42, 103054. [CrossRef]

4. Bustos García, A.; Cobo Escamilla, A.; González Yunta, F. Mejora de las propiedades mecánicas de los morteros de cal hidráulica por adición de fibras de basalto. In Proceedings of the $2^{\circ}$ Congreso Internacional de Innovación Tecnológica en Edificación (CITE 2017), Madrid, Spain, 8-10 March 2017; pp. 260-261, ISBN 978-84-16397-56-3.

5. Ministerio de Transporte, Movilidad y Agenda Urbana (MITMA). Available online: https://www.mitma.gob.es/ (accessed on 29 August 2021).

6. Pérez Fargallo, A.; Calama Rodríguez, J.M.; Flores Alés, V. Comparativa de resultados de rehabilitación energética para viviendas en función del grado de mejora. Inf. Construcción 2016, 68, 541. [CrossRef]

7. De Gobierno, P. Real Decreto 2429/1979, de 6 de Julio, por el Que se Aprueba la Norma Básica de Edificación NBE-CT-79, Sobre Condiciones Térmicas en los Edificios; No. 253; BOE: Madrid, Spain, 1979; pp. 24524-24550.

8. Lei, L.; Chen, W.; Wu, B.; Chen, C.; Liu, W. A building energy consumption prediction model based on rough set theory and deep learning algorithms. Energy Build. 2021, 240, 110886. [CrossRef]

9. Huang, B.; Gao, X.; Xu, X.; Song, J.; Geng, Y.; Sarkis, J.; Fishman, T.; Kua, H.; Nakatani, J. A Life Cycle Thinking Framework to Mitigate the Environmental Impact of Building Materials. One Earth 2020, 3, 564-573. [CrossRef]

10. Thormark, C. Conservation of energy and natural resources by recycling building waste. Resour. Conserv. Recycl. 2001, 33, 113-130. [CrossRef]

11. Objetivos Para el Desarrollo Sostenible (Naciones Unidas). Available online: https://www.un.org/sustainabledevelopment/es/ objetivos-de-desarrollo-sostenible/ (accessed on 31 August 2021).

12. Villoria Sáez, P.; Omani, M. A diagnosis of construction and demolition waste generation and recovery practice in the European Union. J. Clean. Prod. 2019, 241, 118400. [CrossRef]

13. González, M.D.; Plaza Caballero, P.; Fernández, D.B.; Jordán Vidal, M.M.; del Bosque, I.F.S.; Medina Martínez, C. The Design and Development of Recycled Concretes in a Circular Economy Using Mixed Construction and Demolition Waste. Materials 2021, 14, 4762. [CrossRef]

14. European Commission (2018): Guidelines for the Waste Audits before Demolition and Renovation Works of Buildings. Available online: https:/ / ec.europa.eu/growth/content/eu-construction-and-demolition-waste-protocol-0_en (accessed on 5 September 2021).

15. Villoria Sáez, P.; del Rio, M.; San-Antonio González, A.; Porras-Amores, C. Best practice measures assessment for construction and demolition waste management in building constructions. Resour. Conserv. Recycl. 2013, 75, 52-62. [CrossRef]

16. Gharfalkar, M.; Court, R.; Campbell, C.; Ali, Z.; Hillier, G. Analysis of waste hierarchy in the European waste directive 2008/98/EC. Waste Manag. 2015, 39, 305-313. [CrossRef] [PubMed]

17. European Commission (2019b), COM(2019) 640. The European Green Deal. Available online: https:/ / eur-lex.europa.eu/resource. html?uri=cellar:b828d165-1c22-11ea-8c1f-01aa75ed71a1.0002.02/DOC_1\&format=PDF (accessed on 31 August 2021).

18. Superti, V.; Houmani, C.; Binder, C.R. A systemic framework to categorize Circular Economy interventions: An application to the construction and demolition sector. Resour. Conserv. Recycl. 2021, 173, 105711. [CrossRef]

19. López-Ruiz, L.A.; Roca Ramón, X.; Gassó Domingo, S. The circular economy in the construction and demolition waste sector-A review and an integrative model approach. J. Clean. Prod. 2020, 248, 119238. [CrossRef]

20. Stefanidou, M.; Anastasiou, E.; Georgiadis Filikas, K. Recycled sand in lime-based mortars. Waste Manag. 2014, 34, $2595-2602$. [CrossRef] [PubMed]

21. Faria, P.; Henriques, F.; Rato, V. Comparative evaluation of lime mortars for architectural conservation. J. Cult. Herit. 2008, 9 , 338-346. [CrossRef]

22. Saeli, M.; Senff, L.; Tobaldi, D.M.; Seabra, M.P.; Labrincha, J.A. Novel biomass fly ash-based geopolymeric mortars using lime slaker grits as aggregate for applications in construction: Influence of granulometry and binder/aggregate ratio. Constr. Build. Mater. 2019, 227, 116643. [CrossRef]

23. Torres, I.; Matias, G.; Faria, P. Natural hydraulic lime mortars-The effect of ceramic residues on physical and mechanical behaviour. J. Build. Eng. 2020, 32, 101747. [CrossRef]

24. Pozo-Antonio, J.S. Evolution of mechanical properties and drying shrinkage in lime-based and lime cement-based mortars with pure limestone aggregate. Constr. Build. Mater. 2015, 77, 472-478. [CrossRef]

25. Apostolopoulou, M.; Bakolas, A.; Kotsainas, M. Mechanical and physical performance of natural hydraulic lime mortars. Constr. Build. Mater. 2021, 290, 123272. [CrossRef]

26. González-Cortina, M.; Villanueva-Domínguez, L. Aired ime and chamotte hydraulic mortars. Mater. Constr. 2002, 52, 65-76.

27. Bustos-García, A.; Moreno-Fernández, E.; Yunta-González, F.; Cobo-Escamilla, A.A. Influencia de la adición de fibras en las propiedades de los morteros de cal hidráulica. DYNA 2018, 93, 228-232. [CrossRef]

28. Maravelaki-Kalaitzaki, P. Hydraulic lime mortars with siloxane for waterproofing historic masonry. Cem. Concr. Res. 2017, 37, 283-290. [CrossRef]

29. Forster, A.M.; Válek, J.; Hughes, J.J.; Pilcher, N. Lime binders for the repair of historic buildings: Considerations for $\mathrm{CO}_{2}$ abatement. J. Clean. Prod. 2020, 252, 119802. [CrossRef] 
30. Ergenç, D.; Fort, R. Accelerating carbonation in lime-based mortar in high $\mathrm{CO}_{2}$ environments. Constr. Build. Mater. 2018, 188, 314-325. [CrossRef]

31. Chen, K.; Wang, J.; Yu, B.; Wu, H.; Zhang, J. Critical evaluation of construction and demolition waste and associated environmental impacts: A scientometric analysis. J. Clean. Prod. 2021, 287, 125071. [CrossRef]

32. Instituto Nacional de EstadísticaEstadística Sobre Generación de Residuos en el Sector Servicios Y Construcción. Año 2017. Cantidad de Residuos Generados por Actividad Económica CNAE-2009, Clase de Residuo y Tipo de Peligrosidad. 2017. Available online: https: / / www.ine.es /jaxi/Tabla.htm?path=/t26/e068/p03/a2017/10/\&file=01001.px\&L=0 (accessed on 16 July 2021).

33. Peixoto-Rosado, L.; Vitale, P.; Penteado, C.S.G.; Arena, U. Life cycle assessment of natural and mixed recycled aggregate production in Brazil. J. Clean. Prod. 2017, 151, 634-642. [CrossRef]

34. Etxeberría, M.; Vázquez, E.; Marí, A.; Barra, M. Influence of amount of recycled coarse aggregates and production process on properties of recycled aggregate concrete. Cem. Concr. Res. 2007, 37, 735-742. [CrossRef]

35. Piña Ramírez, C. Comportamiento físico-mecánico y térmico de los morteros de cemento aditivados con fibras minerales procedentes de residuos de construcción y demolición. Ph.D. Thesis, E.T.S. de Edificación (UPM), Madrid, Spain, 2018. [CrossRef]

36. Milling, A.; Mwasha, A.; Martin, H. Exploring the full replacement of cement with expanded polystyrene (EPS) waste in mortars used for masonry construction. Constr. Build. Mater. 2020, 253, 119158. [CrossRef]

37. Ali, Y.A.Y.; Fahmy, E.H.A.; Abouzeid, M.N.; Shaheen, Y.B.I.; Abdel Mooty, M.N. Use of expanded polystyrene wastes in developing hollow block masonry units. Constr. Build. Mater. 2020, 241, 118149. [CrossRef]

38. Koksal, F.; Mutluay, E.; Gencel, O. Characteristics of isolation mortars produced with expanded vermiculite and waste expanded polystyrene. Constr. Build. Mater. 2019, 236, 117789. [CrossRef]

39. Piña, C.; Vidales, A.; Serrano-Somolinos, R.; del Rio, M.; Atanes-Sánchez, E. Analysis of fire resistance of cement mortars with mineral wool from recycling. Constr. Build. Mater. 2020, 265, 120349. [CrossRef]

40. Fantilli, A.P.; Sicardi, S.; Dotti, F. The use of wool as fiber-reinforcement in cement-based mortar. Constr. Build. Mater. 2017, 139, 562-569. [CrossRef]

41. Boynton, R.S. Chemistry and Technology of Lime and Limestone; John Wiley \& Sons Inc.: New York, NY, USA, 1980.

42. UNE-EN 459-1:2002. Building Lime-Part 1: Definitions, Specifications, and Conformity Criteria. Available online: https: / / www.en.une.org/encuentra-tu-norma/busca-tu-norma/norma?c=N0027076 (accessed on 18 January 2022).

43. UNE 80103:2013. Test Methods of Cements. Physical Analysis. Actual Density Determination. Available online: https: / / www.une.org/encuentra-tu-norma/busca-tu-norma/norma?c=N0052011 (accessed on 18 January 2022).

44. Saint-Astier. Data Sheet for NHL 5. Available online: http://www.calhidraulica.es/gama-completa/ (accessed on 18 September 2021).

45. UNE-EN 933-2/1M:1999. Test for Geometrical Properties of Aggregates. Part 2: Determination of Particle Size Distribution. Test Sieves, Nominal Size of Apertures. Available online: https:/ / www.une.org/Buscador (accessed on 18 January 2022).

46. Ontiveros-Ortega, E.; Rodríguez-García, R.; González-Serrano, A.; Molina, L. Evolution of mechanical properties in aerial lime mortars of traditional manufacturing, the relationship between putty and powder lime. Constr. Build. Mater. 2018, 191, 575-589. [CrossRef]

47. NBE FL-90. Norma Básica de Edificación. Muros Resistentes de Fábrica de Ladrillo. Available online: http://www.madrid.org/ bdccm/normativa/PDF/Ladrillos\%20y\%20bloques/Normas\%20Tratadas/ESRd172390.pdf (accessed on 18 January 2022).

48. UNE-EN 13139: 2003. Aggregates for Mortar. Available online: https://standards.iteh.ai/catalog/standards/cen/d1169c31-b2 3e-41fa-8f1d-cf3a9b0ce8dd/en-13139-2002 (accessed on 18 January 2022).

49. UNE-EN 933-1: 2012. Tests for Geometrical Properties of Aggregates—Part 1: Determination of Particle Size Distribution-Sieving Method. Available online: https:/ / www.en-standard.eu/une-en-933-1-2012-tests-for-geometrical-properties-of-aggregatespart-1-determination-of-particle-size-distribution-sieving-method/ (accessed on 18 January 2022).

50. UNE-EN 146404: 2018. Aggregates for Concrete. Determination of the Coefficient of Friability of the Sands. Available online: https:/ / www.mystandards.biz/standard/une-146404-2018-26.12.2018.html (accessed on 18 January 2022).

51. UNE-EN 1097-3: 1999. Tests for Mechanical and Physical Properties of Aggregates_Part 3: Determination of Loose Bulk Density and Voids. Available online: https:/ / www.en-standard.eu/une-en-1097-3-1999-tests-for-mechanical-and-physical-propertiesof-aggregates-part-3-determination-of-loose-bulk-density-and-voids / (accessed on 18 January 2022).

52. UNE-EN 1097-6: 2014. Tests for Mechanical and Physical Properties of Aggregates-Part 6: Determination of Particle Density and Water Absorption. Available online: https:/ /www.en-standard.eu/une-en-1097-6-2014-tests-for-mechanical-and-physicalproperties-of-aggregates-part-6-determination-of-particle-density-and-water-absorption/ (accessed on 18 January 2022).

53. González Madariaga, F.J.; Lloveras Macia, J. EPS (expanded poliestyrene) recycled bends mixed with plaster or stucco, some applications in building industry. Inf. Construcción 2008, 60, 35-43. [CrossRef]

54. Ferrándiz-Mas, V.; García-Alcocel, E. Physical and mechanical characterization of Portland cement mortars made with expanded polystyrene particles addition (EPS). Mater. Construcción 2012, 62, 547-566. [CrossRef]

55. del Río Merino, M.; Santa Cruz Astorqui, J.; González Cortina, M. Morteros aligerados con arcilla expandida: Influencia de la granulometría y la adicción de fibras de vidrio AR en el comportamiento mecánico. Inf. Construcción 2005, 57, 39-46. [CrossRef]

56. Piña-Ramírez, C.; del Rio Merino, M.; Viñas Arrebola, C.; Vidales Barriguete, A.; Kosior-Kazberuk, M. Analysis of the mechanical behaviour of the cement mortars with additives of mineral wool fibres from recycling of CDW. Constr. Build. Mater. 2019, 210, 56-62. [CrossRef] 
57. Morón, A.; Ferrández, D.; Saiz, P.; Morón, C. Experimental Study with Cement Mortars Made with Recycled Concrete Aggregate and Reinforced with Aramid Fibers. Appl. Sci. 2021, 11, 7791. [CrossRef]

58. Canal de Isabel II. Informe Anual Sobre la Calidad del Agua en Madrid; Canal de Isabel II: Madrid, Spain, 2012.

59. UNE-EN 196-1:2018. Methods of Testing Cement-Part 1: Determination of Strength. Available online: https://www.en-standard. eu/une-en-196-1-2018-methods-of-testing-cement-part-1-determination-of-strength/ (accessed on 18 January 2022).

60. UNE-EN 1015-3:2000/A2:2007. Methods of Test for Mortar for Masonry_Part 3: Determination of Consistence of Fresh Mortar (by Flow Table). Available online: https:/ / www.en-standard.eu/une-en-1015-3-2000-a2-2007-methods-of-test-for-mortar-formasonry-part-3-determination-of-consistence-of-fresh-mortar-by-flow-table/ (accessed on 18 January 2022).

61. Vaishnavi, M.; Aswathi, A.; Sri Saarani, S.; Varghese, A.; Sathyan, D.; Mini, K.M. Strength and workability characteristics of coir and nylon fiber reinforced self-compacting mortar. Mater. Today Proc. 2021, 46, 4696-4701. [CrossRef]

62. Serrano, R.; Cobo, A.; Prieto, M.I.; Nieves-González. M. Analysis of fire resistance of concrete with polypropylene or steel fibers. Constr. Build. Mater. 2016, 122, 302-309. [CrossRef]

63. UNE-EN 1015-11:2000/A1:2007. Methods of Test for Mortar for Masonry-Part 11: Determination of Flexural and Compressive Strength of Hardened Mortar. Available online: https://www.en.une.org/encuentra-tu-norma/busca-tu-norma/norma/?c=N0 039892 (accessed on 18 January 2022).

64. UNE-EN 1015-2:1999/A1:2007. Methods of Test for Mortar for Masonry—Part 2: Bulk Sampling of Mortars and Preparation of Test Mortars. Available online: https:/ / www.en-standard.eu/une-en-1015-2-1999-a1-2007-methods-of-test-for-mortar-formasonry-part-2-bulk-sampling-of-mortars-and-preparation-of-test-mortars / (accessed on 18 January 2022).

65. UNE-EN 1015-18:2003. Methods of Test for Mortar for Masonry-Part 18: Determination of Water Absorption Coefficient due to Capillary Action of Hardened Mortar. Available online: https:/ /www.en-standard.eu/une-en-1015-18-2003-methods-of-test-formortar-for-masonry-part-18-determination-of-water-absorption-coefficient-due-to-capillary-action-of-hardened-mortar/ (accessed on 18 January 2022).

66. UNE-EN 12371:2011. Natural Stone Test Methods-Determination of Frost Resistance. Available online: https://www.enstandard.eu/une-en-12371-2011-natural-stone-test-methods-determination-of-frost-resistance/ (accessed on 18 January 2022).

67. UNE-EN 12370:20201. Natural Stone Test Methods-Determination of Resistance to Salt Crystallisation. Available online: https: / / www.en-standard.eu/une-en-12370-2020-natural-stone-test-methods-determination-of-resistance-to-salt-crystallisation / (accessed on 18 January 2022).

68. UNE 80-112-89 Experimental: Métodos de Ensayo de Cementos: Ensayos Físicos: Determinación de la Retracción de Secado y del Hinchamiento en Agua. Available online: https://books.google.com/books/about/UNE_80_112_89_experimental.html?id=Os3 9cQAACAAJ (accessed on 18 January 2022).

69. Pardo, A.; Ruiz, M.A.; San Martín, R. Análisis de Datos en Ciencias Sociales y de la Salud I; Editorial Síntesis: Madrid, Spain, 2015.

70. Pardo, A.; San Martín, R. Análisis de Datos en Ciencias Sociales y de la Salud II; Editorial Síntesis: Madrid, Spain, 2015.

71. Martínez, W.; Alonso, E.M.; Rubio, J.C.; Bedolla, J.A.; Velasco, F.A.; Torres, A.A. Comportamiento mecánico de morteros de cal apagada artesanalmente, adicionados con mucílago de cactácea y ceniza volcánica, para uso en restauración y conservación de monumentos coloniales. Rev. Construcción 2008, 7, 93-101.

72. Alejandre Sánchez, F.J.; Flores Alés, V. Blasco López, F.J. Martín del Río, J.J. La Cal: Investigación, Patrimonio y Restauración; Universidad de Sevilla: Sevilla, Spain, 2014.

73. Piña, C.; del Rio, M.; Viñas, C.; Vidales, A.; Aguilera, P. Durability of cement mortars reinforced with insulation waste from the construction industry. J. Build. Eng. 2021, 40, 102719. [CrossRef]

74. Apostolopoulou, M.; Armaghani, D.J.; Bakolas, A.; Douvika, M.G.; Moropoulu, A.; Asteris, P.G. Compressive strength of natural hydraulic lime mortars using soft computing techniques. Procedia Struct. Integr. 2019, 17, 914-923. [CrossRef]

75. Rigopoulus, I.; Kyriakou, L.; Vasiliades, M.A.; Kyratsi, T.; Efstathiou, A.M.; Ioannou, I. Improving the carbonation of air lime mortars at ambient conditions via the incorporation of ball-milled quarry waste. Constr. Build. Mater. 2021, 301, 124073. [CrossRef]

76. Rita-Santos, A.; Rosario-Veiga, M.; Santos-Silva, A.; de Brito, J.; Ignacio Álvarez, J. Evolution of the microstructure of lime-based mortars and influence on the mechanical behaviour: The role of the aggregates. Constr. Build. Mater. 2018, 187, 907-922. [CrossRef]

77. Morón, A.; Ferrández, D.; Saiz, P.; Vega, G.; Morón, C. Influence of Recycled Aggregates on the Mechanical Properties of Synthetic Fibers-Reinforced Masonry Mortars. Infrastructures 2021, 6, 84. [CrossRef]

78. UNE-EN 998-2:2012. Specification for Mortar for Masonry-Part 2: Masonry Mortar. Available online: https://www.en-standard. eu/une-en-998-2-2018-specification-for-mortar-for-masonry-part-2-masonry-mortar/ (accessed on 18 January 2022).

79. García, G.; González, M.; del Rio, M.; Magdalena, F. Morteros adicionados con metacaolín: Efecto de la proporción del agregado. DYNA 2017, 92, 155-157. [CrossRef]

80. UNE-EN 1015-12:2016. Methods of Test for Mortar for Masonry-Part 12: Determination of Adhesive Strength of Hardened Rendering and Plastering Mortars on Substrates. Available online: https:/ /www.en-standard.eu/une-en-1015-12-2016-methodsof-test-for-mortar-for-masonry-part-12-determination-of-adhesive-strength-of-hardened-rendering-and-plastering-mortarson-substrates / (accessed on 18 January 2022).

81. García López de la Osa, G. Análisis de la Adherencia Entre Morteros y Piezas Cerámicas. Ph.D. Thesis, Universidad Politécnica de Madrid, Madrid, Spain, 2020. 
82. Sáiz Martínez, P.; González Cortina, M.; Fernández Martínez, F.; Rodríguez Sánchez, A. Comparative study of three types of fine recycled aggregates from construction and demolition waste (CDW), and their use in masonry mortar fabrication. J. Clean. Prod. 2016, 118, 162-169. [CrossRef]

83. UNE-EN 1015-10:2000/A1:2007. Methods of Test for Mortar for Masonry-Part 10: Determination of Dry Bulk Density of Hardened Mortar. Available online: https:/ / www.en-standard.eu/une-en-1015-10-2000-a1-2007-methods-of-test-for-mortarfor-masonry-part-10-determination-of-dry-bulk-density-of-hardened-mortar/ (accessed on 18 January 2022).

84. Sáiz Martínez, P. Utilización de arenas procedentes de Residuos de Construcción y Demolición, RCD, en la fabricación de morteros de albañilería. Doctoral Thesis, Universidad Politécnica de Madrid, Madrid, Spain, 2015.

85. Vidales Barriguete, A. Caracterización Fisicoquímica y Aplicaciones de yeso con Adición de Residuo Plástico de Cables Mediante Criterios de Economía Circular. Ph.D. Thesis, Universidad Politécnica de Madrid, Madrid, Spain, 2019. [CrossRef]

86. UNE 102042:2014. Gypsum Plasters. Other Test Methods. Available online: https://infostore.saiglobal.com/en-us/Standards/ UNE-102042-2014-26752_SAIG_AENOR_UNE_AENOR_UNE_58700/en-us/contact_us/ (accessed on 18 January 2022).

87. Silva, B.A.; Ferreira-Pinto, A.P.; Gomes, A.; Candeias, A. Short- and long-term properties of lime mortars with water-reducers and a viscosity-modifier. J. Build. Eng. 2021, 43. [CrossRef]

88. García Morales, S. Metodología de Diagnóstico de Humedades de Capilaridad Ascendente y Condensación Higroscópica, en Edificios Históricos. Ph.D. Thesis, Universidad Politécnica de Madrid, Madrid, Spain, 1995.

89. Escudero Lafont, M.E.; García Morales, S. Historical flat roofs of earth in the Mediterranean: Research for the characterization of the water behavior of the materials of the roofs of Ibiza. Inf. Construcción 2019, 71, 301. [CrossRef]

90. Morón, C.; Ferrández, D.; Saiz, P.; Yedra, E. Measuring system of capillary rising damp in cement mortars. Measurement 2019, 135, 252-259. [CrossRef]

91. Zhao, H.; Ding, J.; Juang, Y.; Xu, G.; Li, W.; Zhang, S.; Wang, P. Investigation on sorptivity and capilalarity coefficient of mortar and their relationship based on microstructure. Constr. Build. Mater. 2020, 265, 120332. [CrossRef]

92. San Antonio González, A.D. Caracterización de Compuestos Eco-Eficientes de Yeso Aligerado con Residuo de Poliestireno extruido (XPS). Ph.D. Thesis, Universidad Politécnica de Madrid, Madrid, Spain, 2017. [CrossRef]

93. Varas-Muriel, M.J.; Fort, R.; Gómez-Heras, M. Assessment of an underfloor heating system in a restored chapel: Balancing thermal comfort and historic heritage conservation. Energy Build. 2021, 251, 111361. [CrossRef]

94. Bicer, A.; Kar, F. Thermal and mechanical properties of gypsum plaster mixed with expanded polystyrene and tragacanth. Therm. Sci. Eng. Progress 2017, 1, 59-65. [CrossRef]

95. 2. UNE-EN 12667:200. Thermal Performance of Building Materials and Products. Determination of Thermal Resistance by Means of Guarded Hot Plate and Heat Flow Meter Methods. Products of High and Medium Thermal Resistance. Available online: https://www.en-standard.eu/une-en-12667-2002-thermal-performance-of-building-materials-and-productsdetermination-of-thermal-resistance-by-means-of-guarded-hot-plate-and-heat-flow-meter-methods-products-of-high-andmedium-thermal-resistance/ (accessed on 18 January 2022).

96. Defus, A.; Sansonetti, A.; Possetini, E.; Tedeschi, C.; Vettori, S.; Realini, M. The effectiveness of di-ammonium hydrogen phosphate (DAP) consolidation treatment on lime-based mortars weathered by freeze-thaw cycles. J. Cult. Herit. 2021, 50, 1-12. [CrossRef]

97. Dong, F.; Wang, H.; Yu, J.; Liu, K.; Guo, Z.; Duan, X.; Quiong, X. Effect of freeze-thaw cycling on mechanical properties of polyethylene fiber and steel fiber reinforced concrete. Constr. Build. Mater. 2021, 295, 123427. [CrossRef]

98. Franzoni, E.; Santandrea, M.; Gentilini, C.; Fregni, A.; Carloni, C. The role of mortar matrix in the bond behavior and salt crystallization resistance of FRCM applied to masonry. Constr. Build. Mater. 2019, 209, 592-605. [CrossRef]

99. Syed Ahmed Kabeer, K.I.; Bisht, K.; Jothi Saravanan, T.J.; Kumar Vyas, A. Effect of marble slurry on the microstructure of cement mortars subjected to salt crystallization and alternate wetting and drying cycles. J. Build. Eng. 2021, 44, 103342. [CrossRef]

100. García-Talegón, J.; Vicente, M.A.; Molina, A. Decay of granite monuments due to salt crystallization in a non-polluted urban environment. Mater. Construcción 1999, 49. [CrossRef]

101. Lu, T.; Li, Z.; Huang, H. Restraining effect of aggregates on autogenous shrinkage in cement mortar and concrete. Constr. Build. Mater. 2021, 289, 123166. [CrossRef]

102. Tang, F.; Li, Z.; Tang, Y.; Chen, Y.; Li, H.N. Simultaneous measurement of shrinkage and coefficient of thermal expansion of mortar based on EFPI sensors with nanometer resolution. Measurement 2020, 152, 107376. [CrossRef]

103. Morón, C.; Saiz, P.; Ferrández, D.; García-Fuentevilla, L. New System of Shrinkage Measurement through Cement Mortars Drying Sensors 2017, 17, 522. [CrossRef] [PubMed] 